\title{
Salt Marsh Accretion With and Without Deep Soil Subsidence as a Proxy for Sea-Level Rise
}

\author{
Han F. van Dobben ${ }^{1}$ D . Alma V. de Groot ${ }^{2}$. Jan P. Bakker ${ }^{3}$
}

Received: 10 June 2021 / Revised: 15 November 2021 / Accepted: 19 November 2021 / Published online: 1 January 2022

(c) The Author(s) 2021

\begin{abstract}
The relation between salt marsh accretion and flooding regime was quantified by statistical analysis of a unique dataset of accretion measurements using sedimentation-erosion bars, on three barrier islands in the Dutch Wadden Sea over a period of c. 15 years. On one of the islands, natural gas extraction caused deep soil subsidence, which resulted in gradually increasing flooding frequency, duration, and depth, and can thus be seen as a proxy for sea-level rise. Special attention was paid to effects of small-scale variation e.g., in distance to tidal creeks or marsh edges, elevation of the marsh surface, and presence of livestock. Overall mean accretion rate was $0.44 \pm 0.0005 \mathrm{~cm}$ year ${ }^{-1}$, which significantly exceeded the local rate of sea-level rise of $0.25 \pm 0.009 \mathrm{~cm}$ year $^{-1}$. A multiple regression approach was used to detect the combined effect of flooding regime and the local environment. The most important flooding-related factors that enhance accretion are mean water depth during flooding and overall mean water depth, but local accretion strongly decreases with increasing distance to the nearest creek or to the salt marsh edge. Mean water depth during flooding can be seen as an indicator for storm intensity, while overall mean water depth is a better indicator for storm frequency. The regression parameters were used to run a simple model simulating the effect of various sea-level scenarios on accretion and show that, even under extreme scenarios of sea-level rise, these salt marshes can probably persist for the next 100 years, although the higher parts may experience more frequent inundation.
\end{abstract}

Keywords Deep subsidence $\cdot$ Elevation change $\cdot$ Suspended sediment concentration $\cdot$ Storm $\cdot$ Autocompaction · Netherlands · Wadden Sea $\cdot$ Terschelling · Ameland $\cdot$ Schiermonnikoog

\section{Introduction}

Salt marshes are among the ecosystems that are most vulnerable to climate change. Regional to global studies have estimated that sea-level rise (SLR) over the twenty-first century could induce the loss of $30-80 \%$ of coastal wetlands, including salt marshes and mangroves (Lovelock et al. 2015; Spencer et al. 2016; Schuerch et al. 2018; Thiéblemont et al.

Communicated by Mead Allison.

Han F. van Dobben

han.vandobben@wur.nl

1 Wageningen Environmental Research, POB 9101, 6700 HB Wageningen, The Netherlands

2 Wageningen Marine Research, Ankerpark 27, 1781 AG Den Helder, The Netherlands

3 Conservation Ecology, Groningen Institute for Evolutionary Life Sciences GELIFES, University of Groningen, P.O. Box 11103, 9700 CC Groningen, The Netherlands
2019). This would imply the loss of habitat for unique flora and fauna, and the loss of valuable ecosystem services (e.g., Brown et al. 2006; Barbier et al. 2011), such as carbon sequestration (e.g., Mcleod et al. 2011) and protection of the hinterland against flooding and shoreline erosion (e.g., Gedan et al. 2011; Shepard et al. 2011; Temmerman et al. 2013). Since salt marshes occur just above mean sea level, their capacity to persist under SLR depends on accretion (Fagherazzi et al. 2020), which we here define as the vertical rise in marsh surface elevation resulting from the sum of sedimentation, erosion, compaction, swelling, and shrinkage of mineral and organic sediments. If sea level rises rapidly, accretion may not be sufficient to keep pace with SLR, which may lead to increasing flooding and ultimately to marsh vegetation die-off and "drowning" of a marsh (e.g., Cooper et al. 2001; Morris et al. 2002; Kirwan and Megonigal 2013; Blankespoor et al. 2014; Schepers et al. 2017).

The factors that govern accretion in salt marshes have been studied extensively (e.g., Townend et al. 2011; Wiberg et al. 2020). Most important are sediment supply (depending 
on suspended sediment concentration (SSC) of the incoming water and supply routes, i.e., distance to the creeks and marsh edge (Van Wijnen and Bakker 2001; Temmerman et al. 2003a; French 2006; Bartholdy et al. 2010a), frequency, depth and duration of inundations (depending on surface elevation, tidal range, and storm frequency and intensity; Temmerman et al. 2003b; Kirwan et al. 2010; Balke et al. 2016), hydrodynamic conditions (Townend et al. 2011; Sassi et al. 2015), the presence of vegetation (Mudd et al. 2010), accumulation of organic matter (Roner et al. 2016), and compaction of the sediment (autonomous but also enhanced by the presence of livestock; Bartholdy et al. 2010b; Elschot et al. 2013).

Present views on salt marsh accretion in response to projected rates of SLR due to climate change are generally based on two approaches. First, they can be based on observed accretion for periods or sites that experienced local SLR rates that can be considered comparable to projected rates of future global SLR. Today, global mean SLR rate is about $0.25 \mathrm{~cm}$ year $^{-1}$ (Nicholls et al. 2021), and it is projected that this can accelerate to values of 1 to $2 \mathrm{~cm} \mathrm{year}^{-1}$ by 2100 (Rahmstorf 2007; Church et al. 2013). Over recent years, several meta-analyses have compiled published accretion data for salt marshes and mangroves (e.g., Lovelock et al. 2015; Kirwan et al. 2016; Crosby et al. 2016; Jankowski et al. 2017). These studies summarize observations from many sites (typically $>100$ ) subject to a wide range of historic rates of local SLR, from a few mm year ${ }^{-1}$ to $>1 \mathrm{~cm} \mathrm{year}^{-1}$. However, these analyses were based on datasets of relatively short time series (mostly < 10 years; or e.g., single storm events) and for sites across large regions (typically 10 to $1000 \mathrm{~s} \mathrm{~km}$ apart). Short-term data have the disadvantage of not incorporating long-term processes, such as compaction of sediments (e.g., Bartholdy et al. 2010b; Parkinson et al. 2017) and weather extremes such as storms (e.g., Schuerch et al. 2013; Leonardi et al. 2018). Furthermore, in studies comparing accretion data across large regional scales, explanatory variables (such as SLR rate, tidal range, SSC, vegetation type) tend to co-vary between sites. This makes it difficult to isolate the response to SLR rate from the response to other variables. While the short-term data disadvantage may be compensated by using meta-analyses on long-term (century to millennial scale) sedimentary salt marsh records (e.g., Horton et al. 2018), still such meta-analyses are typically for sites across large regional scales (Wiberg et al. 2020).

Secondly, several numerical models have been developed to assess the response of salt marshes to future SLR scenarios (e.g., see Fagherazzi et al. 2012 for a review, or more recently Schuerch et al. 2018). Such models predict that marsh accretion rate increases with increasing rate of SLR, through increased tidal flooding and, hence, increased supply and deposition of mineral and organic sediments (e.g., Temmerman et al. 2003a; French 2006; Kirwan et al. 2010).
This feedback mechanism allows marshes to accrete faster as SLR accelerates, until a critical SLR rate is exceeded, above which drowning of a marsh is predicted. The critical SLR rate is predicted to vary between sites depending on SSC and tidal range (Kirwan et al. 2010). As a consequence, a more rapid loss of coastal marshes is predicted by models that assume a constant accretion rate, whereas models that incorporate a feedback between the rate of SLR and accretion rate are less pessimistic (Kirwan et al. 2016). Again, data to calibrate or validate such accretion models either come from a single site with a specific SLR history (e.g., Morris et al. 2002) or from multiple sites at distant locations with different SLR histories but also different in other controlling factors such as SSC, vegetation type, and tidal range (e.g., Temmerman et al. 2004; Schuerch et al. 2018). Therefore, studies comparing salt marsh accretion in nearby sites, with similar environmental conditions such as tidal range, SSC, and vegetation type, but subject to different historic rates of SLR, could close a gap in present insights, but are lacking so far.

Studies on salt marsh accretion with accelerating rates of SLR, both from meta-analyses of empirical data and from numerical model assessments, mostly neglect small-scale variation in accretion rate within a marsh. Short-term sediment accretion rates (measured over single tides to one or a few years) can vary at short distances $(\sim 10-100 \mathrm{~m})$ within marshes, e.g., as a result of progressive sediment trapping along supply routes from marsh edges towards the marsh platform (e.g., Christiansen et al. 2000; Leonard et al. 2002; Temmerman et al. 2003b). However, meta-analyses aiming to increase insights in marsh accretion in response to different SLR rates typically consider regional-scale variations between distant sites but neglect the small-scale within-site variability (e.g., Lovelock et al. 2015; Kirwan et al. 2016; Crosby et al. 2016; Jankowski et al. 2017; Rodrígues et al. 2017). Also, model assessments of long-term (decades) marsh response to SLR scenarios do not consider such small-scale gradients (e.g., Fagherazzi et al. 2012; Wiberg et al. 2020). Consequently, poor knowledge exists on the importance of small-scale within-site variability in controlling the capacity of salt marsh accretion rates to keep up with accelerated SLR.

In the present paper, we bring together data from three adjacent barrier islands in the Dutch Wadden Sea, collected in several studies that differed in aim and background but had accretion measurements by "sedimentation-erosion Bars" (SEB; Nolte et al. 2013a) as a common feature (see Supplementary Material). Beneath one of these islands (Ameland), deep (c. $2 \mathrm{~km}$ ) extraction of natural gas has been going on since 1986, causing subsidence of the surface layers at a rate of c. $0.7 \mathrm{~cm}_{\text {year }}{ }^{-1}$. Together with the background SRL rate of c. $0.25 \mathrm{~cm}$ year $^{-1}$, this results in a relative SLR rate in the order of $1 \mathrm{~cm} \mathrm{year}^{-1}$, i.e., comparable to projected 
rates of global mean SLR towards the end of the twenty-first century. The two neighboring islands did not experience gas extraction and associated deep subsidence and were subject to the background SLR only. Because of their proximity (within a range of c. $60 \mathrm{~km}$ ), our plots have comparable vegetation, SSC, and tidal range. This creates the unique opportunity to compare salt marsh accretion with and without accelerated SLR, but under otherwise comparable conditions. Our plots have different positions relative to creeks or the salt marsh edge, and, hence, capture small-scale within-marsh variability in response to accelerated SLR. In addition, some plots are grazed by livestock and some are not.

Our aims are the following: (1) to quantify the relation between salt marsh accretion rate and flooding regime, and more specifically, the dependence of this relation on smallscale, within-site variation in environmental factors such as distance to tidal creeks or marsh edges, elevation of the marsh surface, and presence of livestock; (2) to determine the effect of different SLR rates on accretion by comparing nearby sites with and without artificially accelerated SLR (through deep subsidence); and (3) to use the found relations to assess the ability of the studied salt marsh sites to survive under various SLR scenarios, with rates between 0.2 and $0.8 \mathrm{~cm}$ year $^{-1}$ over a 100 -year period.

\section{Methods}

\section{Study Sites}

Our study focuses on the adjacent Dutch islands of Terschelling, Ameland, and Schiermonnikoog (Fig. 1). They are part of the Wadden Sea islands (or West-Frisian Islands), a chain of barrier islands located along the North Sea coasts of the Netherlands, Germany, and Denmark (Esselink et al. 2017). Many of these islands have sand-drift dikes or dunes that shelter extensive areas of back-barrier salt marsh from the North Sea (Ehlers 1988; Oost et al. 2012). The western sides of these islands are inhabited and their salt marshes have mostly been developed into polders, but the salt marshes on the eastern (downdrift) sides have a high degree of naturalness. Large areas of salt marsh spontaneously developed after the construction of sand-drift dikes in the period 1850-1950. There are no ditches or groins to enhance sedimentation, and only local stone revetments have been constructed to combat edge erosion (Dijkema and Wolff 1983; De Groot et al. 2017).

Sedimentation is predominantly minerogenic and the marshes are characterized by a relatively thin layer (mostly $10-60 \mathrm{~cm}$ ) of silty sediments overlying the sandy subsoil (De Groot et al. 2011). Deposited clay minerals in the Wadden Sea are mostly illite and kaolinite (Van Straaten 1954; He et al. 2012). Mean tidal ranges are 223, 203, and $228 \mathrm{~cm}$, respectively, in the stations Nes, Wierumergronden en Schiermonnikoog (Fig. 1). Mean background rate of SLR during the period 1994-2012 in our stations was $0.25 \pm 0.009 \mathrm{~cm} \mathrm{year}^{-1}$ (derived by regression of all 10 min gauge readings on time; mean value reported for The Netherlands is $0.13-0.27 \mathrm{~cm}_{\text {year }}{ }^{-1}$; Baart et al. 2012; Klein Tank et al. 2015; Vermeersen et al. 2018). Water levels are strongly influenced by atmospheric conditions, notably storms. Suspended sediment concentrations are also strongly influenced by storms, mean value at the water surface in our basins is $10-50 \mathrm{~g} \mathrm{~m}^{-3}$ (Sassi et al. 2015). However, mean SSC is probably not a good predictor for salt marsh accretion because most sediment originates from resuspension

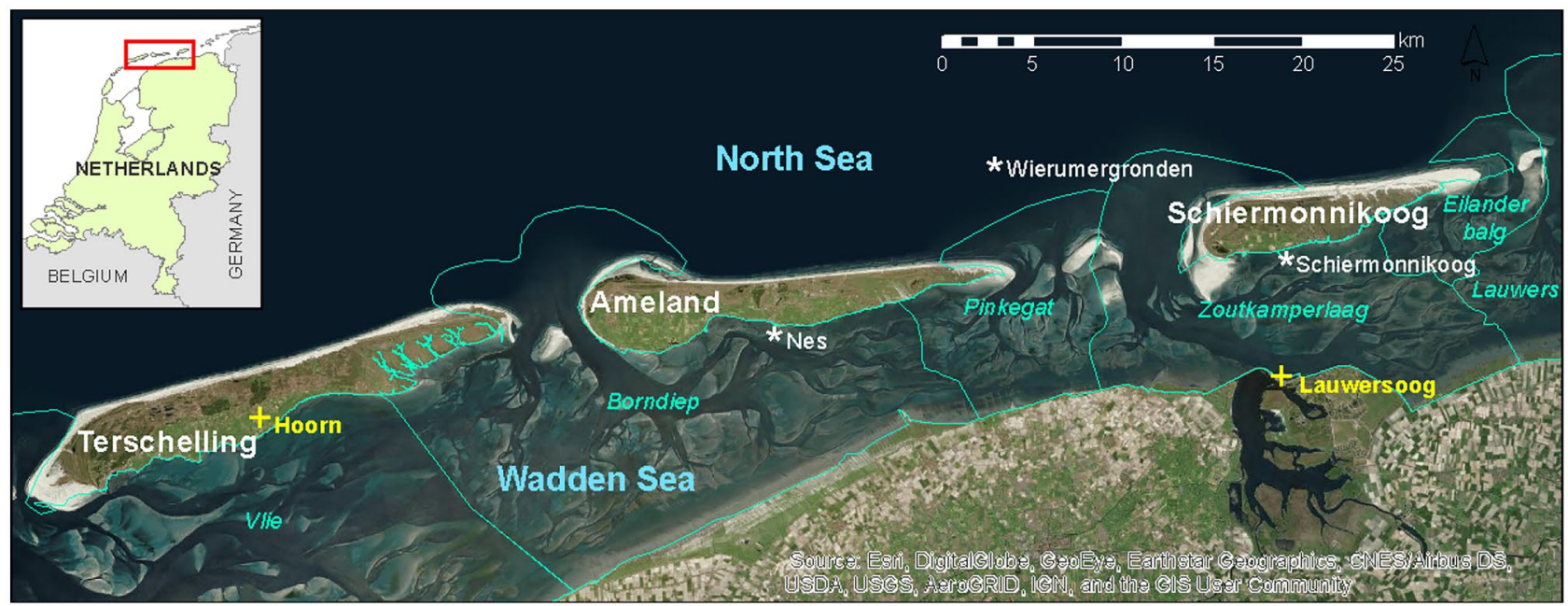

Fig. 1 Location of islands (names in white), tidal basins (names and boundaries in green), tidal gauges (asterisks, white), and weather stations (plusses, yellow) used in our study 
during storms of material deposited earlier on intertidal flats (Schuerch et al. 2014).

The vegetation of our marshes is described by Esselink et al. (2017), and, in more detail, by Leendertse et al. (1997) for Terschelling, Dijkema et al. (2011) for Ameland and Olff et al. (1997) for Schiermonnikoog. The first plant species that establish on intertidal flats are Salicornia spp. and Spartina anglica. When marshes become higher by vertical accretion, they develop into suitable habitat for late-successional species, such as the dwarf shrub Atriplex portulacoides and the herbs Limonium vulgare, Artemisia maritima, and Suaeda maritima on the low marsh, and the tall grass Elytrigia atherica on the high marsh. During succession, vegetation height increases up to $80 \mathrm{~cm}$, and clay content of the upper layer up to $40 \%$ (Schrama et al. 2012), whereas above-ground biomass increases from 200 to $800 \mathrm{~g} \mathrm{~m}^{-2}$ (dry weight), and below-ground biomass from 800 to $1600 \mathrm{~g} \mathrm{~m}^{-2}$ (Van Wijnen and Bakker 1999).

On each island, between 5 and 45 plots were equipped with SEBs; these plots were located in clusters that will further be referred to as sites. Differences between the sites in the numbers and locations of the plots and the number of holes per SEB are a consequence of the heterogeneous origin of our data (see Supplementary Material). On Ameland, the sites have the form of transects from low to high marsh (Fig. 2). Two sites were studied here: Neerlands Reid (AME_ NLR; Table 1; Fig. 2) where a salt marsh developed after the construction of a sand-drift dike around 1890, and De Hon (AME_HON) that developed spontaneously after 1960 behind a naturally formed row of dunes (Slim et al. 2011). Neerlands Reid is grazed by cattle and horses, whereas De Hon is not grazed by livestock. Natural gas extraction has resulted in continuous deep subsidence since 1986 (Piening et al. 2017). The subsidence rate at the soil surface varies throughout the affected marshes and has a decreasing temporal trend, with an overall mean of $0.71 \mathrm{~cm} \mathrm{year}^{-1}$ (range 0.3-1.4 $\mathrm{cm} \mathrm{year}^{-1}$ ) at our plots (Table 1). The sum of that rate and local SLR rate is $0.96 \mathrm{~cm}_{\text {year }}{ }^{-1}$, which is comparable to the rate of SLR currently expected in the IPPC scenarios for The Netherlands $\left(0.2-0.8 \mathrm{~cm}_{\text {year }}{ }^{-1}\right.$, Van den Hurk et al. 2014), and the deep subsidence can therefore be considered an experimentally induced additional SLR (Van Dobben and Slim 2012).

On Terschelling, the salt marsh developed after the construction of a large sand-drift dike between 1931 and 1938 (Roozen and Westhoff 1985). It is not grazed by livestock (Van Wijnen and Bakker 2001). Two sites were studied here (TER_T3 and TER_T4; Table 1; Fig. 2) that mainly differed in distance to the nearest creek. The salt marsh of Schiermonnikoog has continuously expanded eastward over the past 200 years, leading to spontaneously formed marshes whose age increases from east to west (for details see De Groot et al. 2011). Six sites were studied here, all located in the lower salt marsh (from east to west: $\mathrm{SCH} \_\mathrm{T} 0, \mathrm{SCH} \_\mathrm{T} 1$, SCH_T2, SCH_T3, SCH_T5, and SCH_OBK; Table 1; Fig. 2); of these, SCH_T5 lies behind a sand-drift dike since the 1960s, and SCH_OBK is grazed by cattle.

\section{Measurements}

\section{Accretion and Surface Elevation Change}

A SEB plot (Fig. 3) consists of two or three PVC poles of $7.5 \mathrm{~cm}$ in diameter and $100-180 \mathrm{~cm}$ in length that are driven into the soil $2 \mathrm{~m}$ apart, to a depth of at least $1 \mathrm{~m}$ (Nolte et al. 2013a). The poles are driven into the sandy subsoil, and the SEBs, therefore, only measure changes in thickness of the surface layer and not deep subsidence. The poles protrude $10-50 \mathrm{~cm}$ above the soil surface and are made level to each other. The elevation of the poles relative to NAP (Amsterdam ordnance datum, approximately mean sea level) was determined by relating them to local government benchmarks using geodetic methods, on Ameland (with subsidence) also by spatial and temporal interpolation between 3 -yearly precision leveling of benchmarks using a geostatistical model; details are given in Supplementary Material. For measuring, an aluminum bar with 17 holes that are $10 \mathrm{~cm}$ apart is placed over the poles, and elevation of the marsh surface relative to the top of the poles is measured by lowering a measuring stick through each hole. Accretion $(\mathrm{cm}$ year $^{-1}$ ) is calculated as the difference in average readings per SEB between subsequent measurements. It is the sum of sedimentation, erosion, compaction, and swelling or shrinkage, which may result in both positive or negative values over 1-year intervals (Van Duin et al. 1997). We assume that sedimentation is strongly dominant over vertical erosion in our marshes (Friedrichs and Perry 2001; Wang et al. 2018). We will use the term subsidence for the deep subsidence caused by gas extraction (not measured by the SEBs), compaction for a permanent decrease in thickness of the clay layer (measured by the SEBs), accretion for the year-to-year changes in SEB readings, and elevation change when the change in SEB readings was corrected for deep subsidence by relating the elevation of the SEB pole heads to ordnance datum (Fig. 3). In plots without subsidence, the latter two are essentially the same. We did not measure shallow subsidence in the sense of Lynch et al. (2015), i.e., compaction of the sand layer between the pole bottom and the upper surface of the sand layer, as we consider it to be negligible on our time scale (cf. Nolte et al. 2013a). In contrast to studies using marker horizons (Nolte et al. 2013a; Lynch et al. 2015), our accretion includes the compaction, shrinkage, and swelling that take place over the full thickness of the clay layer (see Fig. 3). In total, we used 85 plots divided over 10 sites, where yearly measurements were taken over time spans that varied per plot (range 10-20 years, Table 1), which yielded 

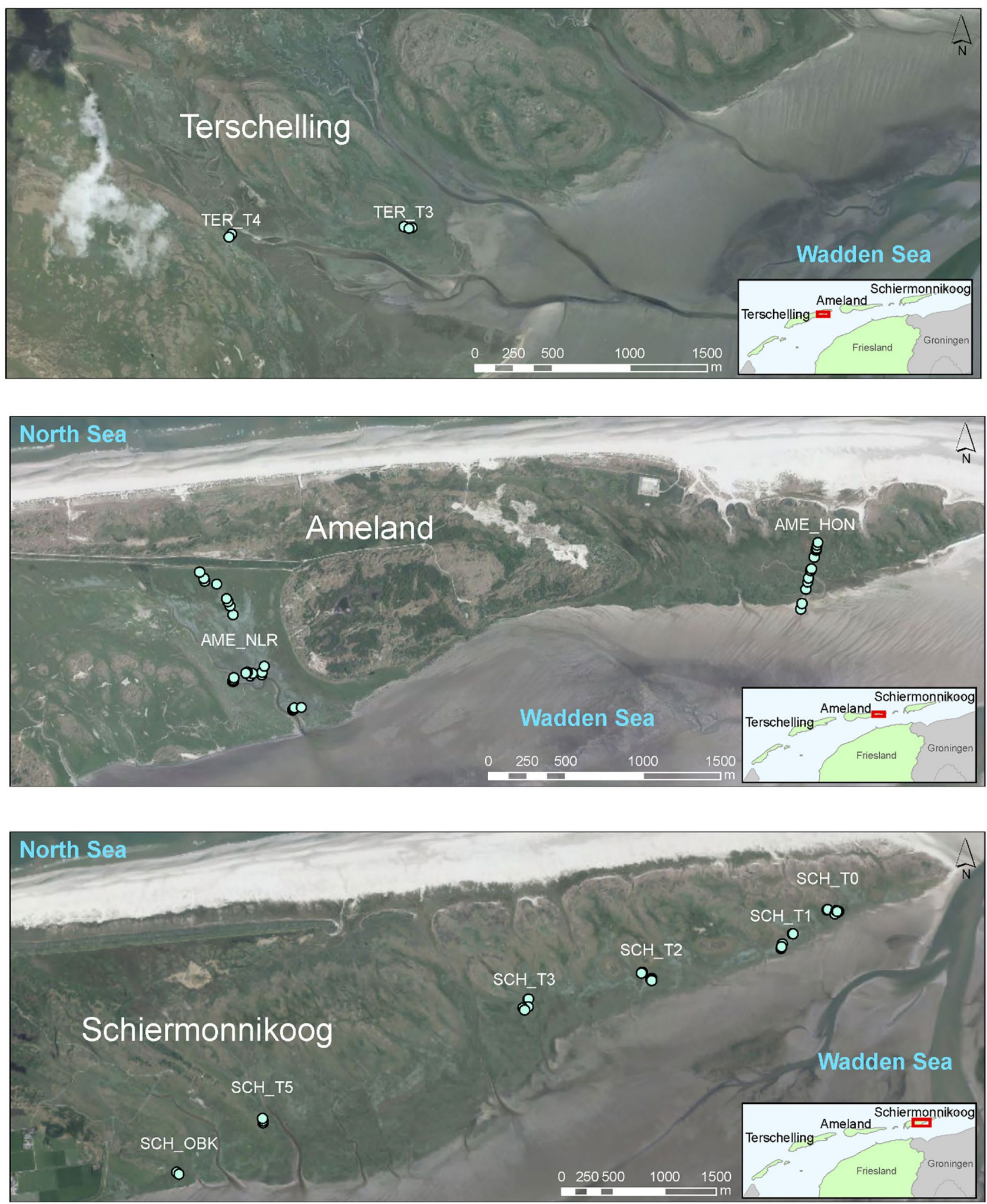

Fig. 2 Location of plots (circles) on the three islands, with their site IDs (see Table 1) (note the difference in scale between the lowermost figure and the two above) 


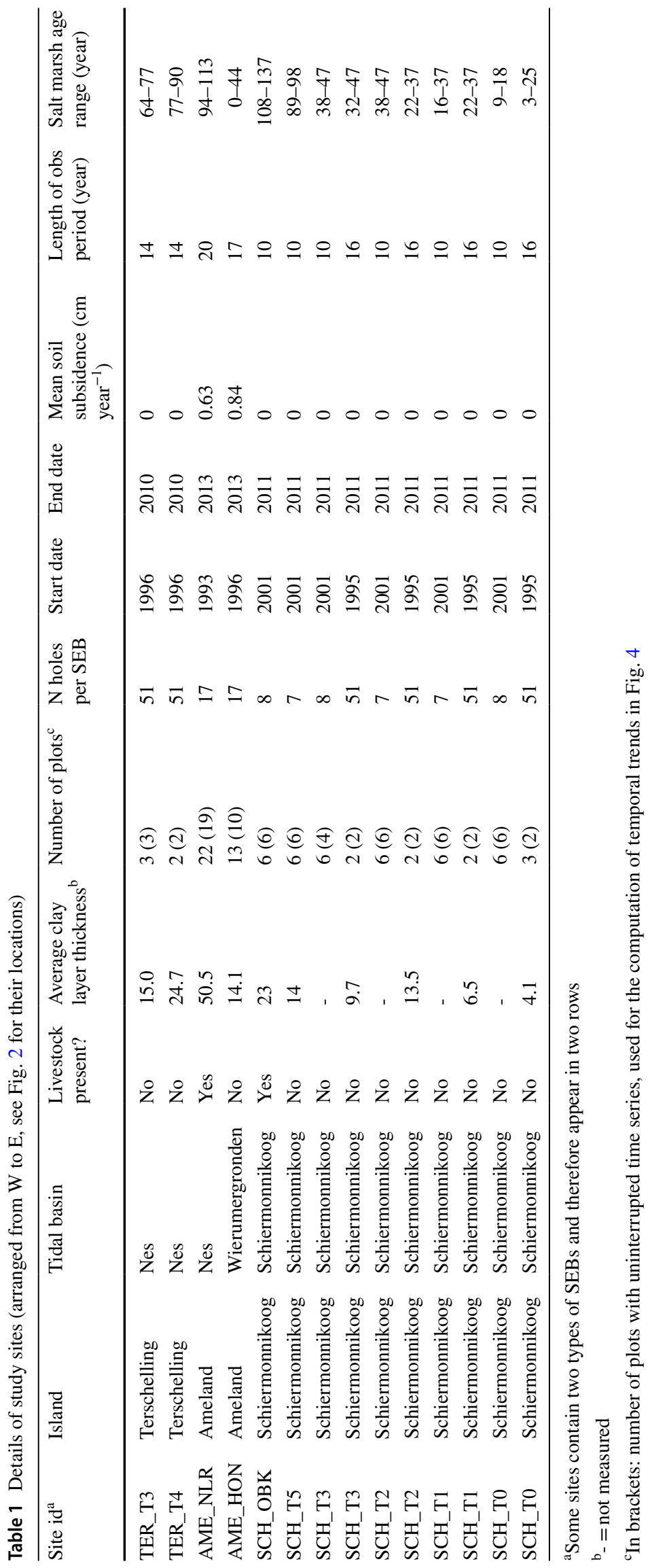




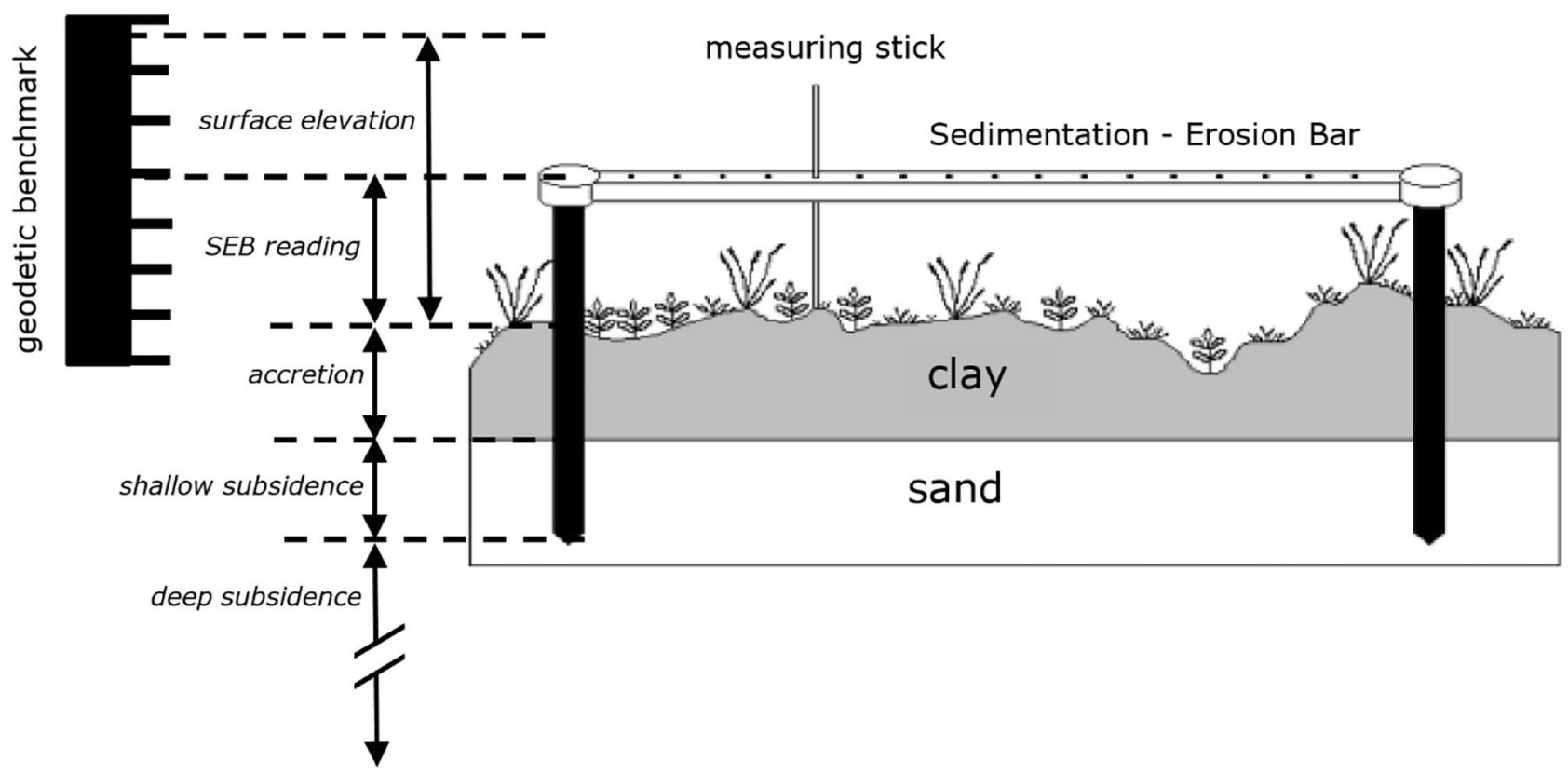

Fig. 3 Diagram of SEB plot. After the measurements the SEB is removed, the poles are permanent. Names of variables in italics. Accretion rate and elevation change follow from repeated SEB measurements. After Dijkema et al. (2011), adapted

1116 useable measurements of accretion over $\sim 1$-year periods. Further details are given in Supplementary Material.

\section{Explanatory Variables}

Water levels relative to NAP were obtained from the Dutch Water Authority (RWS), in 10-min intervals from automated tidal gauges at the stations Nes, Wierumergronden, and Schiermonnikoog which we consider representative for the tidal basins where our plots were located (see Table 1 and Fig. 1). Precipitation and evaporation were obtained from The Royal Netherlands Meteorological Institute (KNMI), using daily values from the weather station Hoorn (Terschelling; Fig. 1); occasional missing values were replaced by values from the weather station Lauwersoog (on the mainland, close to Schier-monnikoog; Fig. 1). Daily net precipitation was computed by subtracting evaporation from precipitation.

The locations of creeks and the marsh edges were digitized from aerial photographs. Following Temmerman et al. (2003b), we determined the shortest distance of each SEB plot to the nearest creek (or to the marsh edge if that is shorter), and the distance along the creek between the point nearest to each plot and the marsh edge (further referred to as "creek length") (set to zero for plots closer to the marsh edge than to a creek). We estimated the age (i.e., the number of years since it became vegetated) of each SEB plot by using a combination of historical records and aerial photographs from various sources (Olff et al. 1997; De Groot et al. 2011; Dijkema et al. 2011; Slim et al. 2011; Elschot et al. 2017). We measured the thickness of the clay layer on a subset of the plots in 2005 or 2006 using a soil auger (see Table 1, for details).

\section{Analysis}

\section{Explanatory Variables}

We used regression analysis to model accretion rate as the sum of (1) vertical sedimentation and erosion, (2) swelling and shrinkage of the clay layer as a result of differences in water content between subsequent measurements, and (3) gradual compaction of the clay layer, that may be enhanced as a result of trampling by livestock. We assumed sedimentation to be dependent upon flooding regime and sediment settling from the incoming water, which in turn depends on the distance to the marsh edge or to the nearest creek and the length of that creek (cf. Temmerman et al. 2003b; Bartholdy et al. 2010a). The full regression model is given in Supplementary Material; its variables will be explained below.

We characterized flooding regime by means of four indicators: flooding frequency, fraction of time that a plot is flooded, overall mean water depth, and mean water depth during flooding periods (see Supplementary Material for details). These indicators were computed for all time intervals at all plots, on the basis of the dates of each pair of subsequent measurements at a given plot and the average of the surface elevations at these dates, using the water levels measured in the tidal basin where that plot is located. 
Water levels at the plots are not necessarily equal to those at the tidal gauges as local hydrodynamics may cause either attenuation or amplification of the recorded tide (Bockelmann et al. 2002; Stark et al. 2015). We tested two procedures to correct for these differences: (a) using fixed differences in water level (gauge minus plot) of $-5,0,5$, 10 , and $15 \mathrm{~cm}$; and (b) using a location-dependent difference in water level, taking account of tidal attenuation or amplification in the creek and on the salt marsh platform. Based on data in Stark et al. (2015), we assumed $4 \mathrm{~cm} \mathrm{~km}^{-1}$ amplification of the tide in creeks, and $35 \mathrm{~cm} \mathrm{~km}^{-1}$ attenuation of the tide on the platform. As a result, 4 (for the flooding regime indicators) $\times 6$ (for the level correction terms $)=24$ terms for flooding regime are available. For the sake of simplicity, only terms with the same correction for attenuation or amplification were tested simultaneously. In practice, only one or two of these terms are included in a regression model because they are strongly intercorrelated (Table S4) and precautions were taken against the inclusion of collinear predictors.

We assumed suspended sediment concentration on the marsh platform to decrease with distance to the creek following a negative exponential decay function with a decay constant of -0.069 (on a natural-log basis), i.e., $50 \%$ of the sediment is lost per $10 \mathrm{~m}$ (see Supplementary Material for further explanation). In the creeks, where the sediment loss is much lower than on the marsh platform, we assumed a linear decrease of sediment concentration with distance.

We assumed the (irreversible) autocompaction of the clay layer between subsequent observations to be proportional to the time interval between these observations, at a rate dependent on the clay layer thickness. However, measurements of this thickness were not available for all plots and only at a single point in time (Table 1), and we, therefore, used the age of the salt marsh as a proxy (Olff et al. 1997; De Groot et al. 2011). We ran a separate regression to check whether this is a plausible assumption (see Supplementary Material).

The compaction of the clay layer may be enhanced by trampling in the presence of livestock. Besides, grazing changes the vegetation structure which may affect sedimentation rate (Nolte et al. 2013b, 2015). We accounted for these effects by assuming an extra compaction in the presence of livestock (we did not take account of stocking density which is usually unknown) (see Supplementary Material).

Changes in water content lead to (reversible) swelling or shrinkage of the clay layer, and consequently to differences in measured surface elevation (Van Wijnen and Bakker 2001). We estimated the apparent effect of differences in water content of the clay layer on accretion between subsequent measurements on the basis of the difference in total net precipitation during the two 10-day periods before both observation dates, assuming a linear effect of this variable on accretion (see Supplementary Material). As the absolute amount of swelling or shrinkage may depend on the thickness of the clay layer, we also tested the effect of the interaction term (difference in net precipitation $) \times($ marsh age $)$ (the latter variable again as a proxy for the thickness of the clay layer).

Although we considered many factors that determine accretion rate, it may still be influenced by other, unknown factors. For example, there may be differences between the sites that are not accounted for; in particular, this is the case with subsidence on Ameland. Such differences will lead to an apparent effect of the sites themselves, and these were therefore also included in the analysis as a set of indicator variables, one for each site with value 1 for plots in that site and else 0 .

\section{Model Selection}

The flooding regime indicators had a highly skewed distribution and were normalized by applying a $\ln (X+1)$ transformation. As explained above, the sediment concentration is assumed to exponentially decrease with distance to a creek, and therefore, the distance between each plot and the nearest creek was $\exp (-0.069 . \mathrm{X})$ transformed. All other variables were more or less normally distributed and analyzed untransformed. Table S3 gives basic statistics for all numerical explanatory variables, and Table $\mathrm{S} 4$ their mutual correlations.

A selection procedure was used to arrive at a set of statistical models that are the best approximations of the "true" relation between accretion rate and its predictors. For this procedure, two a priori considerations were made: (1) there are strong correlations among the (transformed) candidate predictors (Table S4), and (2) there is a certain amount of pseudo-replication in the data; both between subsequent observations at each plot, and among the plots in each site. We attempted to deal with these restrictions by using a twostep procedure. In the first step, the most promising candidate models were selected using multiple linear regression. This was done by testing all possible models with one term, with two terms, etc., until a single model with all terms was reached (12,288 models in total; see Supplementary Material for details). For each term, in each model, the variance inflation factor (VIF, as a measure for the mutual correlation between explanatory variables; see Montgomery and Peck (1982: Sect. 8.4.2) was determined. Subsequently, all models were discarded that contained one or more terms whose regression coefficient was not significantly $(P<0.05)$ different from zero, or one or more terms whose VIF was larger than 2. Of the remaining 1297 models, a subset of 100 with the highest percentage explained variance $\left(R^{2}{ }_{\text {adjusted }}\right)$ was considered suitable candidates for further selection. All these models have percentages of explained variance $\left(R_{\text {adjusted }}^{2}\right)$ in the order of $35 \%$. 
In the second step, the selected candidate models were compared in a residual maximum likelihood (REML) procedure using three variance components: the sites, the SEB plots within each site, and the subsequent observations within each SEB plot. We used Akaike's Information Criterion as a measure for goodness-of-fit. For each model, we determined the Akaike weight ( $w$; Symonds and Moussalli 2011), and we considered the models with the highest $w$ up to a summed $w$ of 0.96 (i.e., the smallest set of models with a $96 \%$ probability that the "true" model is among these). We also determined the Akaike weight for each predictor as the sum of the weights of all models in which it occurs. This weight can be seen as the probability that this predictor is a component of the "true" model (Symonds and Moussalli 2011). Further computational details are given in Supplementary Material.

\section{Prediction Model}

To estimate salt marsh behavior under SLR, we calculated accretion over a 100-year period using the parameter values of a subset of the regression models with the highest probability in the previous step, i.e., the best models up to a cumulative Akaike weight of 0.96 . The most probable rate of SLR for the Netherlands up to 2100 according to IPCC AR5 climate scenarios is between 0.2 and $0.8 \mathrm{~cm}_{\text {year }}{ }^{-1}$ (cf. Van den Hurk et al. 2014). On that basis, we considered four scenarios, viz. a rise in mean level of $0.2,0.4$, and $0.8 \mathrm{~cm}$ year $^{-1}$, and a rise that linearly increases from 0.2 to $0.8 \mathrm{~cm} \mathrm{year}^{-1}$ over a 100 -year period. For the other variables, we used the (initial) values for various locations on a hypothetical marsh given in Table 2 . We used a time step of one year, and in each year, we calculated the expected accretion on the basis of the initial values in Table 2, the number of years since the start of the run, and the expected values for the flooding characteristics in that year. We generated a baseline scenario of flooding regime by calculating values for each of its four characteristics, for a range of surface elevations $0.1 \mathrm{~cm}$ apart, between 70 and $190 \mathrm{~cm}+$ NAP (see Supplementary Material for details). In each time step, the simulated accretion was added to the absolute elevation, from which the SLR was subtracted to give a sea-level corrected elevation, which was used as input in the next time step. No elevation change was calculated when the sea-level corrected elevation was outside the range of the training set (i.e., 70-190 cm). This procedure was applied to each of the models in our subset so that a range of simulated elevation changes is formed. As this subset had a cumulative Akaike weight of 0.96 and hence a $96 \%$ probability to contain the "true" model, this range can be seen as a $96 \%$ confidence interval.

\section{Results}

\section{Observed Accretion}

On average, there was a steady accretion in all sites; however, on Ameland, the surface elevation decreased due to deep subsidence (Fig. 4). Significant $(P<0.05)$ differences in mean accretion rate were recorded between the sites (Fig. 5) and between the islands, with Terschelling (mean $0.11 \mathrm{~cm} \mathrm{year}^{-1}$ ) $<$ Schiermonnikoog $\left(0.40 \mathrm{~cm} \mathrm{year}^{-1}\right)<$ Ameland $\left(0.53 \mathrm{~cm} \mathrm{year}^{-1}\right)$. The decrease in accretion rate with increasing marsh age on Schiermonnikoog, i.e., from east ( $\left.\mathrm{SCH}_{-} \mathrm{T} 0\right)$ to west (SCH_T5) is also clearly visible in Fig. 5 (cf. Van Wijnen and Bakker 1997; De Groot et al. 2011). The larger range of accretion rates on Ameland compared to the other two islands (Fig. 5) is a direct consequence of the wider spatial range of the Ameland sites (cf. Fig. 2). Although the mean accretion rate over all plots and all time intervals was $0.44 \pm 0.0005 \mathrm{~cm}_{\text {year }}{ }^{-1}$ and thus significantly exceeded the locally measured SLR rate of $0.25 \pm 0.009 \mathrm{~cm}$ year $^{-1}$, the mean accretion rate of the Terschelling sites was significantly lower than SLR rate. This is probably a consequence of a low sediment deposition caused by either a long distance to the nearest creek (site TER_T3) or a long transport distance through that creek (site TER_T4) (cf. Fig. 2), in combination with a high surface elevation and thus a low flooding frequency. However, the elevation of these plots (mean $126 \pm 0.3 \mathrm{~cm}+\mathrm{NAP}$ ) is far above the lower limit for the occurrence of salt marsh
Table 2 Combinations of (initial) values used for the model runs (precipitation change was set to zero in all runs)

\begin{tabular}{lllll}
\hline Location & $\begin{array}{l}\text { Initial elevation } \\
(\mathrm{cm}+\mathrm{NAP})\end{array}$ & $\begin{array}{l}\text { Initial age } \\
(\text { year })\end{array}$ & $\begin{array}{l}\text { Distance to creek } \\
(\mathrm{m})\end{array}$ & Creek length (m) \\
\hline Marsh edge & 75 & 0 & 1 & 0 \\
Levee (low) & 100 & 20 & 1 & 200 \\
Levee (high) & 140 & 60 & 1 & 500 \\
Marsh platform, & 70 & 0 & 250 & 0 \\
increasing elevation & 100 & 20 & 250 & 200 \\
& 140 & 60 & 250 & 500 \\
& 180 & 100 & 250 & 1000 \\
\hline
\end{tabular}




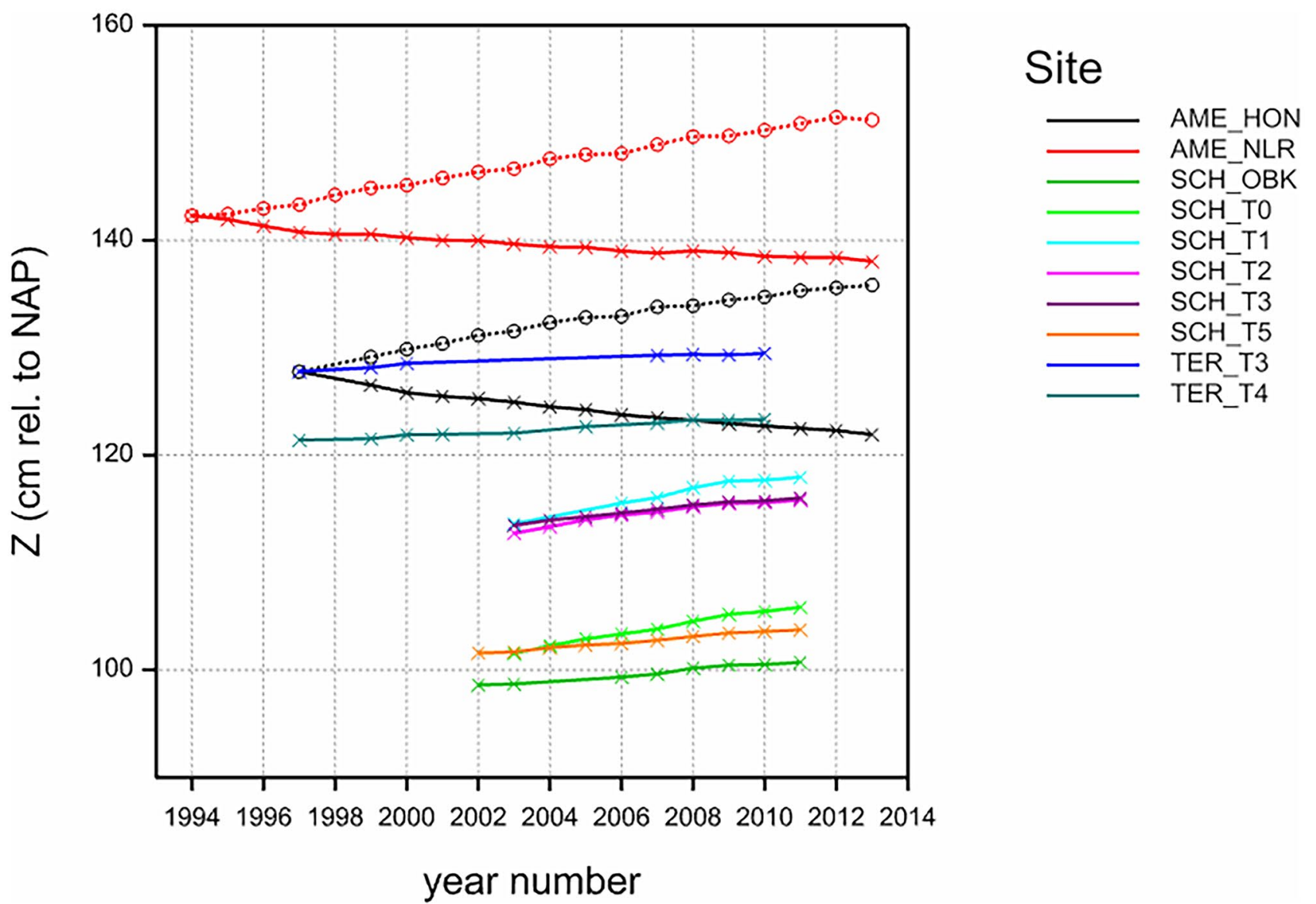

Fig. 4 Average surface elevation over time relative to NAP per site (x), and for the sites at Ameland also the accretion (=surface elevation minus deep subsidence) (o). Averages per site are based on a selection of plots with observations in all years; see Table 1 for their numbers

vegetation (c. $70 \mathrm{~cm}+\mathrm{NAP}$; Dijkema et al. 2011), so these plots have little risk of drowning.

\section{Predictors for Accretion}

The Akaike weights for all tested predictors, based on the 100 best-fitting models selected by linear regression, revealed that the terms for flooding had a very high probability to be in the "true" model (Table 3a). This is also the case for the intercept, distance to the nearest creek, distance to the salt marsh edge through that creek, and the interaction term precipitation $\times$ age (Table $3 b$ ). This probability was far lower for both age-dependent compaction terms (autonomous, or through trampling) and the main effect of precipitation, although these terms had a significant effect in some of the models. Terms for the individual sites did not appear in any of the 100 best-fitting models. The regression coefficients of the 13 best-fitting models (with a summed Akaike weight of 0.96) are given in Table S5.

The overall sum of the Akaike weights for the flooding characteristics (1.986 i.e., nearly two; Table 3a) indicates that the "true" model most probably contains two of these terms. Both mean flooding depth and overall mean water depth have a high probability to be in the "true" model; for the other two characteristics, this probability is far lower (cf. sum column of Table $3 \mathrm{a}$ ). The effect of the correction terms for attenuation or amplification is less clear. A locationdependent amplification or attenuation has a higher probability than a constant value, but low and constant values ( -5 and $0 \mathrm{~cm}$, i.e., a slight or no amplification) also have a reasonably high probability. The highest values (10 and $15 \mathrm{~cm}$, i.e., a strong attenuation) have low probabilities (cf. sum row of Table $3 a$ ).

The Akaike weights together with the signs of the regression coefficients (Table 3 ) show that the conditions that mostly enhance measured accretion are (1) a short distance to a creek at a point that is at a short distance from the marsh edge, (2) a high precipitation just before data collection (the latter especially on older marshes), (3) a high mean flooding depth (both overall and during flooding periods), and-to a lesser extent-(4) a long flooding duration. The "true" model most probably also contains a negative constant term, which is the extrapolated accretion rate (i.e., subsidence) 
Fig. 5 Boxplot of accretion rates per site. The boxes span the interquartile range of the values per site, so that the middle $50 \%$ of the data lie within the box, with a horizontal line indicating the median. The vertical lines enclose the full range of values per site. Sites are ordered to decreasing median. Letters indicate significant $(P<0.05)$ differences of the mean; see Table 1 for the numbers of observations

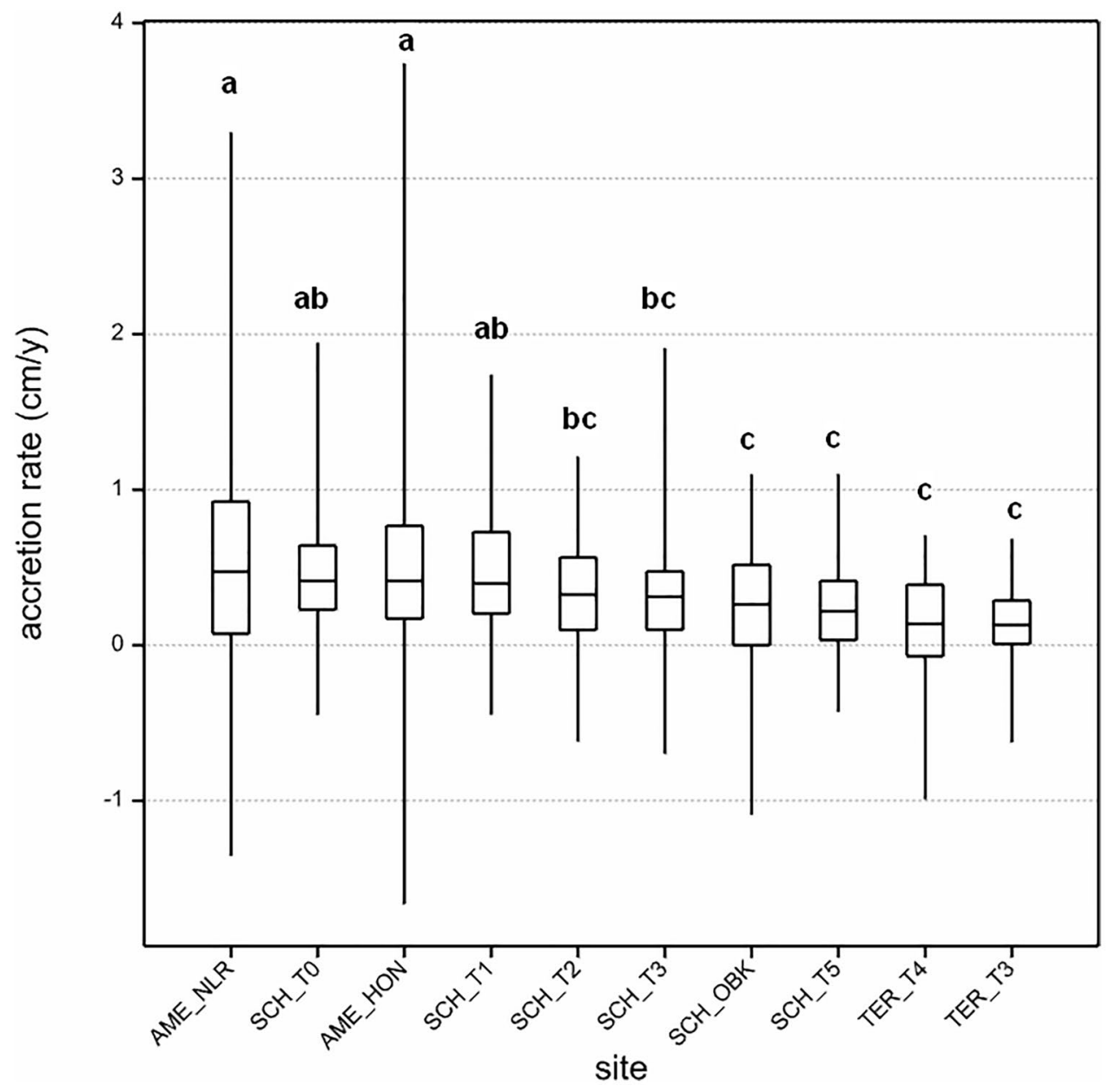

in the absence of flooding, zero creek length, and infinite distance to the nearest creek. We consider this, together with the low Akaike weights of both compaction terms, as an indication that there is considerable autocompaction which is however independent of salt marsh age or the presence of livestock.

\section{Accretion Under Sea-Level Rise Scenarios}

A number of "typical" situations that differed in age and position on the marsh, given in Table 2, were used as starting points to simulate accretion under four scenarios, viz. a mean rate of SLR of $0.2,0.4$, and $0.8 \mathrm{~cm} \mathrm{year}^{-1}$, and a rate that linearly increases from 0.2 to $0.8 \mathrm{~cm}$ year ${ }^{-1}$, over a 100-year period. Simulated accretion over the $100-$ year period, both "absolute" (i.e., relative to NAP; black lines) and corrected for SLR (i.e., relative to NAP + SLR; red lines) strongly differed between the situations given in Table 2 (Fig. 6). The model uncertainty (apparent from the range of black or red lines which can be seen as the $96 \%$ confidence interval) appeared to be small compared to the differences in accretion under different scenarios, and there was a large effect of distance to the nearest creek or to the marsh edge. Parts of the salt marsh that are close to the marsh edge (top row in Fig. 6) or to a creek (rows 2 and 3 ) are expected to survive even the highest rate SLR used in our scenarios, i.e., a constant value of $0.8 \mathrm{~cm}$ year $^{-1}$ (Fig. 6). For the marsh platform (the four bottom rows), the expectations are less favorable. Only at the lowest surface elevation $(70 \mathrm{~cm}+\mathrm{NAP})$, we expect a positive or near-zero accretion relative to SLR, and in all other situations, the rate of SLR is expected to exceed accretion rate. At the highest elevation of $180 \mathrm{~cm}+$ NAP, the accretion even became negative because autocompaction is expected to exceed sediment deposition. However, in none of the simulated situations, "drowning" of the salt marsh took place within 100 years, i.e., the sea-level corrected elevation always remained $>70 \mathrm{~cm}+\mathrm{NAP}$ (the lower limit for the occurrence of salt marsh vegetation in the Netherlands, i.e., the boundary between salt marsh and intertidal flat; Dijkema et al. 2011).

In the long run, a salt marsh will survive if accretion equals or exceeds SLR, i.e., if there is a positive accretion surplus (Fig. 7). At plots that are farthest removed from creeks, the 
Table 3 Akaike weights per predictor, based on the 100 best-fitting models: a, flooding characteristics; $b$, other predictors. Weights for the flooding characteristics are given for different values of the correction term for amplification (negative) or attenuation (positive) of water levels (loc.dep =location-dependent value, see text for explanation). All 100 best-fitting models have equal signs for their regression coefficients, and these are also given in Table b; all flooding characteristics in Table a have positive regression coefficients $(N=1116)$

\begin{tabular}{|c|c|c|c|c|c|c|c|}
\hline \multirow{2}{*}{$\begin{array}{l}\text { a } \\
\text { Predictor } \\
\text { Amplification/ } \\
\text { attenuation } \\
\text { correction }(\mathrm{cm})\end{array}$} & \multicolumn{7}{|c|}{ Akaike weight } \\
\hline & -5 & 0 & 5 & 10 & 15 & loc.dep & SUM \\
\hline $\begin{array}{l}\text { Flooding } \\
\text { frequency }\end{array}$ & 0.003 & 0.002 & 0.001 & 0 & 0 & 0.001 & 0.007 \\
\hline $\begin{array}{l}\text { Flooding } \\
\text { duration }\end{array}$ & 0.104 & 0.045 & 0.017 & 0.003 & 0 & 0.133 & 0.302 \\
\hline $\begin{array}{r}\text { Overall mean } \\
\text { water depth }\end{array}$ & 0.151 & 0.115 & 0.077 & 0.031 & 0.025 & 0.29 & 0.69 \\
\hline $\begin{array}{l}\text { Mean water } \\
\text { depth during } \\
\text { flooding }\end{array}$ & 0.258 & 0.162 & 0.095 & 0.034 & 0.016 & 0.421 & 0.986 \\
\hline SUM & 0.516 & 0.325 & 0.19 & 0.069 & 0.042 & 0.845 & 1.986 \\
\hline $\begin{array}{l}\mathrm{b} \\
\text { Predictor }\end{array}$ & $\begin{array}{l}\text { Akaike } \\
\text { weight }\end{array}$ & \multicolumn{6}{|c|}{ Sign of regr coeff } \\
\hline Constant & 1 & - & & & & & \\
\hline $\begin{array}{l}\text { Distance to } \\
\text { creek }\end{array}$ & 1 & $+^{\mathrm{a}}$ & & & & & \\
\hline Creek length & 1 & - & & & & & \\
\hline $\begin{array}{l}\text { Precipitation } \\
\times \text { age }\end{array}$ & 0.994 & + & & & & & \\
\hline Autocompaction & 0.015 & - & & & & & \\
\hline $\begin{array}{l}\text { Compaction by } \\
\text { trampling }\end{array}$ & 0.008 & - & & & & & \\
\hline Precipitation & 0.006 & + & & & & & \\
\hline
\end{tabular}

${ }^{\mathrm{a} N e g a t i v e ~ a f t e r ~ e x p o n e n t i a t i o n ~}$

accretion surplus is zero or positive at the present rate of SLR $\left(0.2 \mathrm{~cm}\right.$ year $\left.^{-1}\right)$ below an initial surface elevation of $120 \mathrm{~cm}+$ NAP, which is about the average of our plots. At this elevation, it decreases to $-30--40 \mathrm{~cm}$ when SLR rate increases to $0.8 \mathrm{~cm}$ year $^{-1}$. At an elevation of $<120 \mathrm{~cm}+$ NAP and a shorter distance to a creek $(20 \mathrm{~m})$, the accretion surplus remains positive up to a SLR rate of c. $0.5 \mathrm{~cm} \mathrm{year}^{-1}$, while at a very short distance to a creek ( $1 \mathrm{~m}$, on the levee), it remains positive up to an elevation of $170 \mathrm{~cm}+\mathrm{NAP}$ and the highest tested SLR rate $\left(0.8 \mathrm{~cm}_{\text {year }}{ }^{-1}\right)$.

The feedback between SLR and accretion appears to be non-linear (Fig. 7). If accretion were to increase proportional to the rate of SLR, the lines in the diagram would be horizontal, each line intersecting the corresponding line in Fig. 7 at the left (i.e., at the present rate of SLR). On the other hand, if there were no feedback at all, the lines in the diagram would be vertical with a value equal to $-100 \times($ SLR rate + compaction). However, the lines run at an angle with the horizontal axis. In practice, this means that an increase in the rate of SLR is to some extent, but not completely, compensated by an increase in accretion rate.

\section{Discussion}

\section{Deep Subsidence as a Proxy for Sea-Level Rise}

We found accretion rates in minerogenic back-barrier salt marshes in the order of $0.1-0.5 \mathrm{~cm} \mathrm{year}^{-1}$, with an overall mean of c. $0.44 \mathrm{~cm} \mathrm{year}^{-1}$, which exceeds the local rate of SLR (c. $0.25 \mathrm{~cm} \mathrm{year}^{-1}$ ). The presence of deep subsidence in part of our plots enabled us to build a regression model of accretion rate covering a wide range of flooding regimes, and thus to simulate the effect of hitherto untested SLR scenarios. Our model runs did not yield indications for a strong reduction in surface area of our salt marshes area with SLR, not even under rather pessimistic scenarios of $\mathrm{c}$. $0.8 \mathrm{~cm}$ year $^{-1}$ SLR over a 100 -year period. 
Indicator variables for the sites were included in the pre-selection procedure, but none of them appeared in the selected models. Apparently, there are no important, location-dependent predictors for accretion that we did not consider as explanatory variables. Specifically, this is the case with the deep subsidence that only occurs in both Ameland sites. For example, if the effect of subsidence would come about with a large time-lag, this would lead to a significant, location-dependent effect of these sites. We, therefore, conclude that the variables we considered (flooding regime, position on the marsh, age of the marsh, precipitation difference between subsequent observations) are indeed the master variables that govern the observed accretion, and, consequently, can be used to estimate accretion under future scenarios up to a rate of SLR equal to the sum of the present rates of SLR and subsidence.

The above conclusion is reached in a rather indirect way, and it is tempting to propose an analysis in which accretion rate is directly modeled as a combined effect of rates of soil subsidence and SLR. However, such an analysis is not feasible, mainly because — unlike surface elevation—sea level has a very large temporal variability, even its annual mean. Therefore, SLR rate itself can only be directly used in a statistical model with a low temporal resolution, which in practice would mean using only the first and last observation of our time-series (average SLR rate over the three stations we used, and the period 1994-2012 equals $0.25 \mathrm{~cm}_{\text {year }}{ }^{-1}$; however, average year-to-year differences per station vary between -12 and $+9 \mathrm{~cm}$ ). This leads to a loss in discriminative power which prevents the detection of the additional effect of subsidence over the effect of SLR (analysis not shown).

The Ameland sites appeared to have a significantly higher accretion rate than most of the other sites (Fig. 5). This is partly due to deep subsidence but also to the position of the plots. Figure 2 shows that many plots on Ameland are located close to creeks or on their levees. In fact, about onethird of the plots on Ameland are within $10 \mathrm{~m}$ from creeks, and slightly more than half within $20 \mathrm{~m}$. Out of the plots on the other islands, none is within $20 \mathrm{~m}$ from a creek, and only three are within $50 \mathrm{~m}$ from a creek (data not shown but see Fig. 2). These differences are a consequence of the combination of data sets from different sources (see Supplementary Material). Likewise, the accretion rate in the Terschelling plots was significantly lower than in many of the other plots (Fig. 5), but also, this difference can be sufficiently explained from the position of these plots. Although strictly speaking, our mean value of $0.44 \mathrm{~cm}_{\text {year }}{ }^{-1}$ is only true for the sampled sites, the wide range in position of the plots (high, low, far from, or close to creeks, etc.) makes a strong bias due to uneven positioning unlikely. We are therefore confident that our mean value is a good estimate for the overall accretion rate in back-barrier salt marshes in the Dutch Wadden Sea.

\section{Factors Affecting Accretion Rate}

The factors that mostly affect accretion rate over periods of approximately 1 year in our plots are (in order of decreasing importance as testified by their Akaike weights) flooding regime, distance to the nearest creek, distance to the marsh edge through the nearest creek, and precipitation in relation to age of the marsh (Table 3). Furthermore, the negative value for the intercept, present in all tested models, is an indication for a substantial amount of autocompaction. Agedependent compaction (possibly enhanced by trampling if livestock is present) is unimportant although it has a significant effect in some of the tested models. These factors will be discussed below.

\section{Flooding Regime}

As stated before, the overall sum of flooding regime-related Akaike weights (Table 3a) shows that the "true" model most probably contains two flooding regime indicators. Of the tested indicators, the overall mean water depth and the mean depth during flooding have the highest probability to be in the "true" model (with probabilities of c. 0.7 and c. 1.0, respectively). The mean water depth during flooding is an indicator for storm intensity: a single storm tide with a high water level on parts of the marsh that are not flooded during normal tides results in a high value of this indicator, while the overall mean depth is less influenced. This indicator is not sensitive to storm frequency: any number of consecutive, identical storms results in the same value. On the other hand, the overall mean water depth is an indicator for storm frequency (and to some extent also for their intensity), but also for the position on the marsh: its value increases with decreasing surface elevation. However, on the basis of our data, it is most plausible that the effect of overall mean water depth comes about through storm frequency and not through surface elevation. If position on the marsh were dominant, flooding frequency would appear in a substantial number of models, because this variable is directly related to surface elevation. However, the number of models containing this variable is extremely low (cf. sum column of Table $3 \mathrm{a}$ ). We conclude that accretion rate is strongly positively related to the combination of storm intensity and storm frequency, and hence, that sediment deposition mostly takes place during storm tides. This agrees with conclusions of Schuerch et al. (2013), Goodwin and Mudd (2019), and Bakker et al. (2016) although the latter authors also conclude that extreme storms contribute less to accretion than more frequent minor storms.

Our results suggest only a small amount of attenuation or amplification of the water level between the tidal gauges and the plots on the salt marsh (cf. the bottom row of Table 3a). Near-zero values of the correction term for attenuation or amplification have high probabilities, and there are 

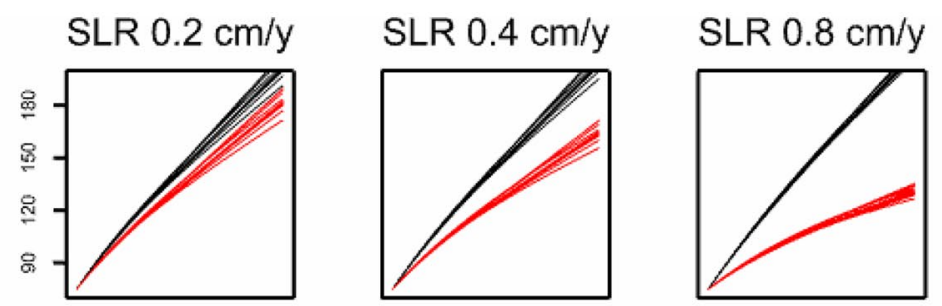

$0.2-0.8 \mathrm{~cm} / \mathrm{y}$

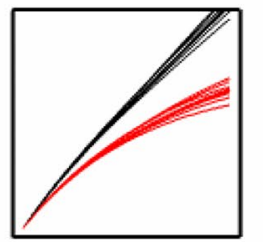

Marsh edge
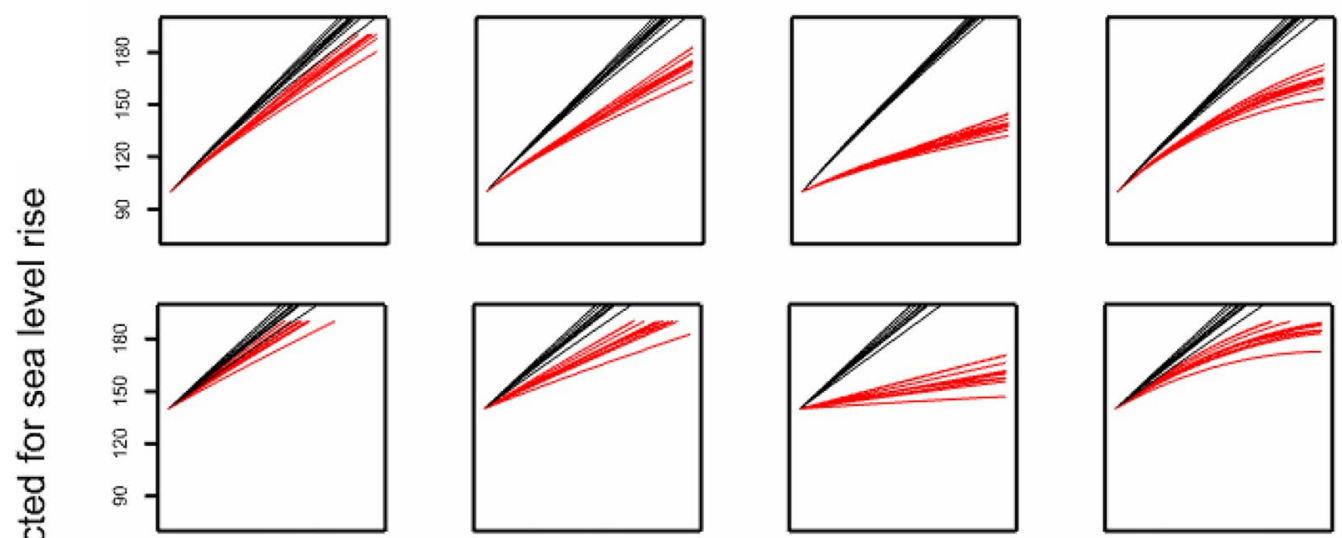

Levee
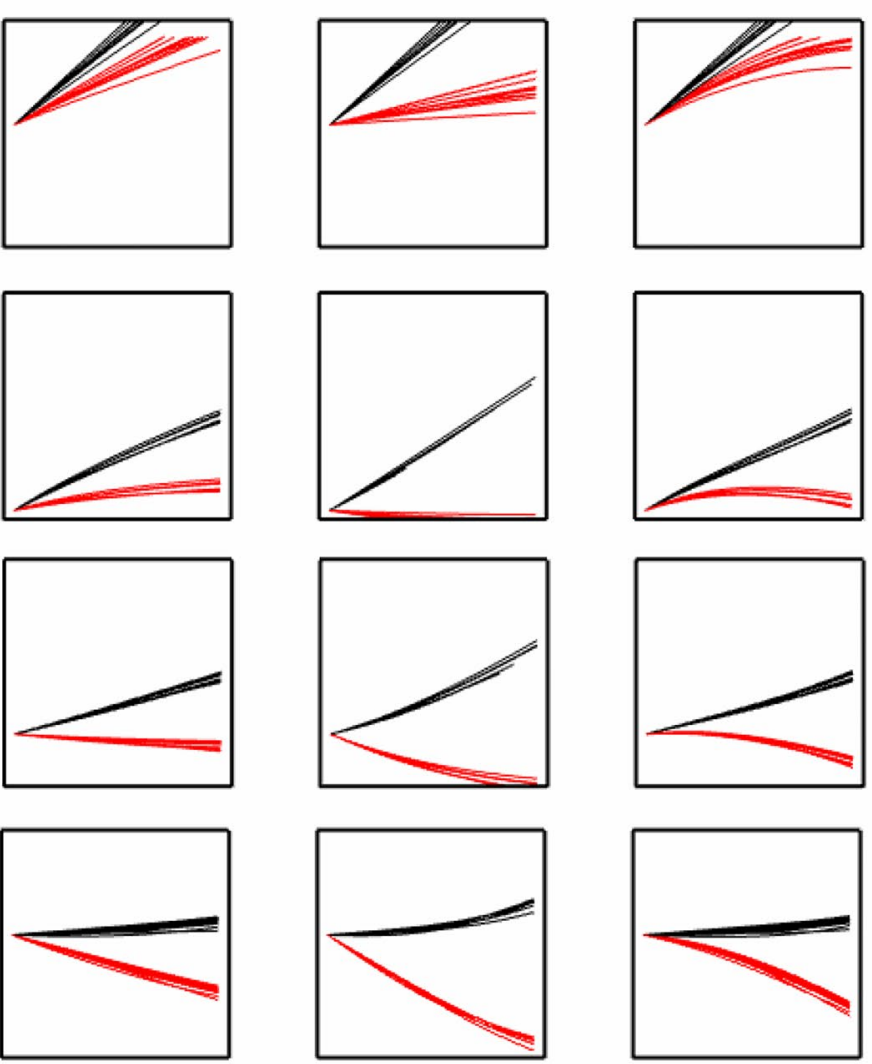

Marsh

platform
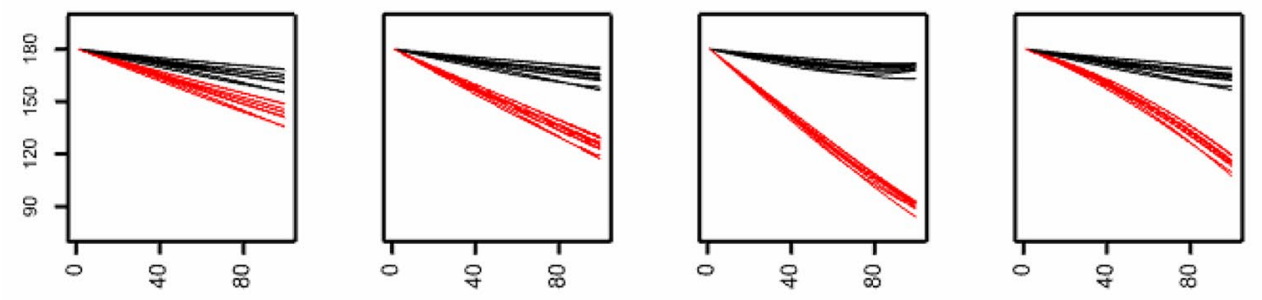

year \# 
4Fig. 6 Projection of salt marsh surface elevation over a 100-year period, relative to NAP (black lines) and relative to NAP + SLR (i.e., corrected for SLR; red lines). Columns represent SLR scenarios, the rightmost one a linearly increasing SLR from 0.2 to $0.8 \mathrm{~cm}_{\text {year }}{ }^{-1}$ over a 100-year period and the others a constant SLR. Rows (from top to bottom) represent initial elevations of $70 \mathrm{~cm}+\mathrm{NAP}$ for the marsh edge, 100 and $140 \mathrm{~cm}+\mathrm{NAP}$ for the levees, and 70, 100, 140, and $180 \mathrm{~cm}+\mathrm{NAP}$ for the marsh platform, respectively; further details are given in the corresponding rows of Table 2. Each line represents one of the 13 best-fitting models (with a cumulative Akaike weight of 0.96). The range of the $Y$-axis spans the elevation range where salt marshes occur (70-200 cm + NAP; Dijkema et al. 2011)

no indications for a strong attenuation. These low values agree with our finding that sedimentation mostly takes place during storm tides. During such tides, friction between the incoming water and the marsh platform is low, and there is a longer time interval for the water level on the platform to reach equilibrium with the incoming level, resulting in a low or zero attenuation (Temmerman et al. 2005; Stark et al. 2015).

\section{Distance to the Nearest Creek and to the Marsh Edge}

Many authors (e.g., Stumpf 1983; French and Spencer 1993; Leonard et al. 1995; Temmerman et al. 2004) found a strongly decreasing SSC and hence, deposition, at increasing distance to the creeks where water is discharged over the marsh platform during high tide. This phenomenon results in the typical levee-platform morphology of salt marshes (Allen 2000; Temmerman et al. 2004). Our analysis confirmed the large effect of distance to the sediment source, with an estimated sediment loss of $50 \%$ over a distance of $10 \mathrm{~m}$. As this value was derived by calibration (details given in Supplementary Material), its uncertainty is rather large, but the results of our regression analyses are not very sensitive to this value. However, changing the negative exponential loss into a linear decrease strongly reduces the fit of the model, from c. $35 \%$ explained variance to c. $26 \%$. In contrast, for creek length, a linear decrease performs just as well as a negative exponential loss (data not shown).

\section{Precipitation, Swelling, Shrinkage, and Compaction}

Over a full drying and rewetting cycle, clay may undergo volume changes in the order of 10-15\% (Basma et al. 1996). Even if changing weather conditions were to influence the wetness of salt marsh soil to a depth of only $10 \mathrm{~cm}$, resulting in only half of the maximum amount of volume change, the resulting change in surface elevation would still be in the order of $0.5 \mathrm{~cm}$. Therefore, the wetness of the soil at the time of SEB measurements has to be taken into account (Nolte et al. 2013a). Even our rough approximation (using recent net precipitation as a measure for wetness, and marsh age as a measure for clay layer thickness) leads to a variable (net precipitation difference between subsequent measurements times marsh age) that has a very high probability to be in the "true" model. The size of the regression coefficients (Table S5) shows that a marsh age of 66 years (the overall mean) and precipitation difference between subsequent measurements of $1000 \mathrm{~mm} \mathrm{year}^{-1}$ (the overall mean of the absolute values) results in a difference in surface elevation of $0.1 \mathrm{~cm}$, i.e., in the order of the overall mean accretion rate of $0.44 \mathrm{~cm} \mathrm{year}^{-1}$. The strong effect of precipitation is surprising because soil wetness is also governed by inundation by seawater. However, average inundation frequency is relatively low in our plots which are typical back-barrier marshes that develop on a sandy slope from dunes to intertidal area. Fifty percent of our plots are inundated less than once per day (Fig. S2). Moreover, our SEB measurements are mostly taken during the period August-October (see Supplementary Material) which is a relatively storm-free period in the North Sea basin (Clemmensen et al. 2014). To our knowledge, this correction has not been used in earlier studies, although Erchinger et al. (1996) and Van Wijnen and Bakker (2001) found that surface elevation measurements in spring tend to yield higher values than those in autumn, which these authors ascribe to a combination of autocompaction (see below) and shrinkage during summer. This observation has led to the general recommendation to compare only SEB measurements taken in the same period of the year (Dijkema et al. 2011; Nolte et al. 2013a), which was also followed in our study (see Supplementary Material).

Differences in surface elevation may not only result from swelling or shrinkage, which is a reversible process, but also from compaction, which is irreversible (Bartholdy et al. 2010b). In autocompaction, the lower part of the clay layer is gradually compressed under the weight of the newly deposited sediment. The magnitude of autocompaction may be considerable, Bartholdy et al. (2010b) found a logarithmic increase of bulk density with depth, and they estimate a doubling of bulk density over the first $20 \mathrm{~cm}$ depth. The general effect of autocompaction is that older marshes, that have a thick clay layer, show a lower accretion rate than young marshes, irrespective of surface elevation (Cahoon et al. 1995; Van Wijnen and Bakker 2001). Compaction may be further enhanced by trampling of livestock (Elschot et al. 2013; Marin-Diaz et al. 2021). We included terms for compaction that is dependent on both marsh-age (as a proxy for clay layer thickness) and the presence of livestock, but we also considered the intercepts of our models as estimates for age-independent autocompaction (see Supplementary Material). The mean of the intercepts in Table S5 is $0.78 \mathrm{~cm} \mathrm{year}^{-1}$, which is quite high compared to Bartholdy et al. (2010a) who estimate c. $0.2 \mathrm{~cm}_{\text {year }}{ }^{-1}$ autocompaction for a 75-year-old marsh (recalculated from their Fig. 9). Some of the candidate models (however, only a few of them and not the best-fitting ones) also have a term for 

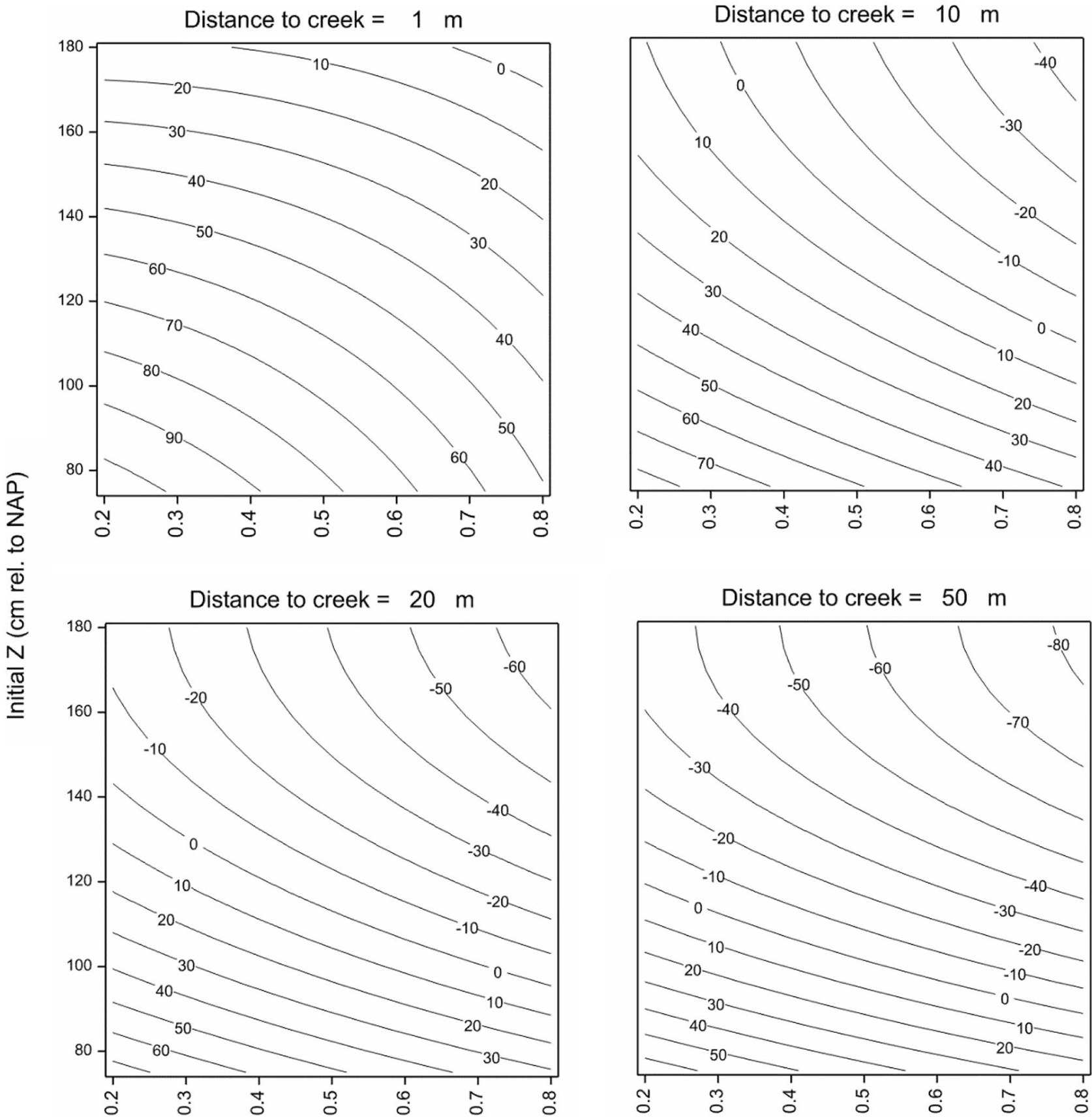

\section{$\operatorname{SLR}(\mathrm{cm} / \mathrm{y})$}

Fig. 7 Contour plots of predicted accretion surplus (=surface elevation change in $\mathrm{cm}$ relative to sea level) after 100 years as a function of initial elevation $(Z)$ and rate of SLR, at various distances to the nearest creek. Simulated values resulting from the model with the highest

age-dependent autocompaction, whether or not dependent on livestock, but the effect of these terms (an increase in compaction by c. $0.13 \mathrm{~cm}_{\text {year }}{ }^{-1}$ ) appears to be smaller than the age-independent autocompaction estimated from the intercepts $\left(\mathrm{c} .0 .78 \mathrm{~cm} \mathrm{year}^{-1}\right)$. These findings are at variance with
Akaike weight have been smoothed by a 2nd-order polynomial. Values of initial age and creek length co-vary with initial $\mathrm{Z}$ according to Table 2. Distances to creek of $>50 \mathrm{~m}$ are not plotted because, above this value, the effect of distance is hardly noticeable

Elschot et al. (2013) and Marin-Diaz et al. (2021) who found a strong effect of trampling. Also, Nolte et al. (2015) found a significant effect of livestock, at least under certain conditions (high precipitation, high inundation frequency). A more detailed study e.g., using exclosures over a prolonged 
period of time would be needed to unequivocally elucidate the effect of livestock on salt marsh compaction and to separate it from autocompaction (Nolte et al. 2013b).

\section{Accumulation of Organic Matter}

In contrast to some North American salt marshes, accretion in salt marshes in the North Sea is mainly due to sedimentation of allochthonous mineral material and not to in situ organic matter production by the vegetation (Friedrichs and Perry 2001; De Groot et al. 2011; French and Spencer 1993; French et al. 1995; Reef et al. 2017). Soil carbon content of the Schiermonnikoog salt marsh is only c. $5-10 \%$ (Elschot et al. 2015). We therefore assumed accumulation of autochthonous organic matter to be negligible. If there would be substantial autochthonous accretion, it is expected to increase with surface elevation (Roner et al. 2016). However, in our data accretion strongly decreases with decreasing flooding, i.e., at higher elevations (Table 3), which adds to the plausibility of the above assumption. However, as both autochthonous and allochthonous accretion correlate with flooding, our regression analysis is not able to discriminate between these sources. Therefore, we cannot exclude a certain amount of accretion by autochthonous organic matter, whose increase at a higher elevation is offset by the concomitant decrease in allochthonous sedimentation. If this is the case, it would increase the resilience of salt marshes to drowning under climate change (Ratliff et al. 2015; Reef et al. 2017).

\section{Impact of Future Sea-Level Rise}

If we assume $0.4-0.8 \mathrm{~cm}_{\text {year }}{ }^{-1}$ as the most probable range for SLR for the next 100 year (Van den Hurk et al. 2014), our simulations show that the seafront, the levees, and the lower and pioneer salt marsh (in the sense of Dijkema et al. (2011), i.e., below $140 \mathrm{~cm}+\mathrm{NAP}$ ) will be able to keep pace with SLR, but that higher parts (the middle and higher salt marsh) will experience more flooding, and hence, its vegetation composition may change into the direction of that of the lower salt marsh. However, real "drowning" in the sense that the surface elevation relative to sea level drops below $70 \mathrm{~cm}+$ NAP (where vegetation would disappear, cf. Dijkema et al. 2011) does not occur in our scenarios (but it could occur at SLR values slightly above $0.8 \mathrm{~cm}_{\text {year }}{ }^{-1}$, cf. Fig. 6, or over longer timespans). The inclusion of plots in the statistical analysis with a subsidence (and thus an additional SLR) in the order of $0.8 \mathrm{~cm}_{\text {year }}{ }^{-1}$ adds to the credibility of this conclusion. It should however be noted that our scenarios are based on Van den Hurk et al. (2014), which in turn is based on the fifth IPCC Assessment Report (Church et al. 2013), and that recently new scenarios have become available in the sixth IPCC Assessment Report (IPCC 2021). We compared our scenarios to the new "medium confidence" predictions and conclude that ours can still be considered realistic. Only pessimistic "low confidence" predictions, entailing e.g., a massive loss of Antarctic ice, produce SLR rates that far exceed our maximum of $0.8 \mathrm{~cm}_{\text {year }}{ }^{-1}$ (Table S7).

Although SLR up to $80 \mathrm{~cm}$ over 100 years will not lead to a loss of marsh area, it may lead to a loss of variation because the higher parts of the salt marsh become lower and the lower parts do not change or become higher relative to sea level. One should also be aware that our scenarios assume a completely static landscape without the formation of new marshes from the intertidal area nor old marshes becoming covered with over-wash or aeolian sand from outside the tidal frame. In a dynamic situation, the formation of new marshes is still possible because the area around the marsh edge has an accretion surplus even under our highest SLR scenario (cf. Kirwan et al. 2016).

Many authors (e.g., French 2006; Kirwan et al. 2010; Schuerch et al. 2013) have attempted to derive "critical values" for SLR, below which drowning of salt marshes would not occur. However, such critical rates strongly depend on tidal range, SSC, and position on the salt marsh (Friedrichs and Perry 2001; Temmerman et al. 2004). Also, as explained by Schuerch et al. (2012), the definition of "marsh survival" may be (1) the ability to stay above the minimum surface elevation that allows characteristic plant growth over a given period (usually 100 years, or up to 2100) (French and Spencer 1993; Bartholdy et al. 2010a; Schuerch et al. 2013), or (2) the ability to maintain an accretion rate at least equal to SLR at the minimum elevation that allows plant growth (e.g., Kirwan et al. 2010; D'Alpaos et al. 2011). One could even adhere to a stricter definition (3): the ability to maintain an accretion rate at least equal to SLR over the entire elevation range.

Kirwan et al. (2010) arrive at a critical SLR of c. $1 \mathrm{~cm} \mathrm{year}^{-1}$ for SSCs and tidal ranges typical for Western Europe, based on an evaluation of five process-driven models and using definition (2). Schuerch et al. (2012) arrive at a critical value of c. $0.2 \mathrm{~cm}_{\text {year }}{ }^{-1}$ for the German Wadden Sea island of Sylt, using definition (1) and a processdriven model. On the basis of our data-driven model and definition (1), the critical SLR would be slightly above $0.8 \mathrm{~cm}$ year $^{-1}$ (cf. Fig. 6, 3rd col., red lines: in the most unfavorable situations the red lines just touch the $X$-axis which is at $70 \mathrm{~cm}+\mathrm{NAP}$ ). Also, in definition (2), our critical SLR would be above the maximum value that we tested $\left(0.8 \mathrm{~cm} \mathrm{year}^{-1}\right)$ (cf. Fig. 7: the accretion surplus is always positive at $70 \mathrm{~cm}+\mathrm{NAP}$, which is about the lower surface elevation limit for plant growth; Dijkema et al. 2011). However, if the strictest definition (3) is used the critical SLR would be around the present-day value of $0.2 \mathrm{~cm}^{\text {year }}{ }^{-1}$ for the average conditions in our back-barrier salt marshes (elevation $120 \mathrm{~cm}+\mathrm{NAP}$, distance to the nearest creek $100 \mathrm{~m}$ ). We conclude that our critical SLR is in the same 
order as Kirwan et al.'s (2010), but considerably higher than Schuerch et al.'s (2012). However, the latter authors argue that an increase in frequency or intensity of storms would substantially increase their critical value because sediment deposition predominantly takes place during storms (Schuerch et al. 2013). Also, our model would arrive at a higher critical value if storms increase, because this would lead to a higher mean water depth, both overall and (if storm intensity increases) during flooding. We did not explore such scenarios in detail because, currently, local climate scenarios do not expect an increase in storms from a direction that would lead to higher floods (Van den Hurk et al. 2014).

\section{Conclusions}

In this paper, we present a unique dataset of salt marsh accretion in the Dutch Wadden Sea area, collected by yearly measurements in 85 plots using Sedimentation-Erosion Bars. Our data span a geographical range of c. $60 \mathrm{~km}$ divided over three islands, a temporal range of c. 15 years, and contain 1116 measurements of accretion over periods of c. 1 year. In one of the islands, natural gas extraction causes deep soil subsidence at a rate of c. $0.7 \mathrm{~cm}_{\text {year }}{ }^{-1}$ at the soil surface, resulting in a gradually increasing flooding frequency, duration, and depth. Thus, deep subsidence can be seen as a proxy for sealevel rise. We conducted a statistical analysis to quantify the relation between salt marsh accretion and flooding regime (whether or not influenced by deep subsidence), with special attention for its dependence on small-scale variation e.g., in distance to tidal creeks or marsh edges, elevation of the marsh surface, and presence of livestock. Our conclusions can be summarized as follows:

- Average accretion rate of back-barrier salt marshes measured by the SEB method over a period of 1-2 decades in three Dutch Wadden Sea islands is $0.44 \pm 0.0005 \mathrm{~cm}_{\text {year }}{ }^{-1}$ which significantly exceeds the present local rate of sealevel rise of $0.25 \pm 0.009 \mathrm{~cm}_{\text {year }}{ }^{-1}$. Because our plots cover a range of nearly all possible positions within a salt marsh we are confident that this is a good estimate of the overall accretion rate of back-barrier salt marshes in the Dutch Wadden Sea.

- Statistical analysis of the full data set, i.e., including plots with and without deep soil subsidence shows that the dominant factors governing accretion rate on the decadal scale are flooding regime and position within the salt marsh. Accretion strongly increases with both storm frequency and storm intensity, and strongly decreases with increasing distance to the nearest creek or to the salt marsh edge.

- There is a significant amount of autocompaction, independent of the age of the marsh. We did not find strong indications for enhanced compaction in the presence of livestock.
- When comparing year-to-year SEB measurements, swelling and shrinkage of the clay layer due to differences in precipitation just before each measurement have to be taken into account.

- Tidal amplification in creeks and attenuation on the marsh platform is of limited importance, probably because accretion mostly takes place during storm tides where friction between the incoming water and the marsh platform is low.

- On the basis of our model results, we expect that our back-barrier salt marshes will not be drowned in the next 100 years under the present (medium confidence) IPCC climate scenarios and local SLR scenarios; accretion at the marsh edge and along creeks is sufficient to keep pace with a constant SLR of $0.8 \mathrm{~cm}_{\text {year }}{ }^{-1}$ over the next 100 year. However, in the inner marsh, the accretion may be insufficient to keep pace with SLR. Also, less realistic IPCC scenarios entailing e.g., massive ice sheet loss in the Antarctic produce SLR rates that may lead to a largescale loss of salt marsh area.

Supplementary Information The online version contains supplementary material available at https://doi.org/10.1007/s12237-021-01034-w.

Acknowledgements We are grateful for the permission granted by "It Fryske Gea" and by "De Vennoot" to undertake our research on their property (Ameland). Various students, PhD students, field assistants, and volunteers of the University of Groningen are acknowledged for collecting the SEB data on Schiermonnikoog and Terschelling. We thank Elze Dijkman (Wageningen Marine Research) for help with GIS, Paul Goedhart (Biometris, Wageningen University and Research) for statistical support, Nanny Heidema (Wageningen Environmental Research) for preparing Figs. 1 and 2, and Pieter A. Slim (Wageningen Environmental Research) for funding acquisition and helpful comments on earlier versions of the manuscript and editing. We are very grateful to Stijn Temmerman (University of Antwerp) for fruitful discussions and comments on earlier versions. We dedicate this paper to the memory of Kees Dijkema.

Funding This study was part of the strategic research program "Sustainable spatial development of ecosystems, landscapes, seas and regions" (KB-24-002-005), and partly funded by the Dutch Ministry of Economic Affairs, Agriculture, and Innovation, and carried out by Wageningen University and Research. Nederlandse Aardolie Maatschappij funded the study on Ameland.

\section{Declarations}

Conflict of Interest The authors declare no competing interests.

Open Access This article is licensed under a Creative Commons Attribution 4.0 International License, which permits use, sharing, adaptation, distribution and reproduction in any medium or format, as long as you give appropriate credit to the original author(s) and the source, provide a link to the Creative Commons licence, and indicate if changes were made. The images or other third party material in this article are included in the article's Creative Commons licence, unless indicated otherwise in a credit line to the material. If material is not included in the article's Creative Commons licence and your intended use is not 
permitted by statutory regulation or exceeds the permitted use, you will need to obtain permission directly from the copyright holder. To view a copy of this licence, visit http://creativecommons.org/licenses/by/4.0/.

\section{References}

Allen, J.R.L. 2000. Morphodynamics of Holocene salt marshes: A review sketch from the Atlantic and Southern North Sea coasts of Europe. Quaternary Science Reviews 19: 1155-1231.

Baart, F., P.H.A.J.M. Van Gelder, J. De Ronde, M. Van Koningsveld, and B. Wouters. 2012. The effect of the 18.6-year lunar nodal cycle on regional sea-level rise estimates. Journal of Coastal Research 28: 511-516.

Bakker, J.P., A.C.W. Baas, J. Bartholdy, L. Jones, G. Ruessink, S. Temmerman, and M. van de Pol. 2016. Environmental impacts - coastal ecosystems. In North Sea region climate change assessment, ed. M. Quante and F. Colijn, 275-314. Heidelberg, New York, Dordrecht, London: Springer Verlag.

Balke, T., M. Stock, K. Jensen, T.J. Bouma, and M. Kleyer. 2016. A global analysis of the seaward salt marsh extent: The importance of tidal range. Water Resources Research 52: 3775-3786.

Barbier, E.B., S.D. Hacker, C. Kennedy, E.W. Koch, A.C. Stier, and B.R. Silliman. 2011. The value of estuarine and coastal ecosystem services. Ecological Monographs 81: 169-193.

Bartholdy, A.T., J. Bartholdy, and A. Kroon. 2010a. Salt marsh stability and patterns of sedimentation across a backbarrier platform. Marine Geology 278: 31-42.

Bartholdy, J., J.B.T. Pedersen, and A.T. Bartholdy. 2010b. Autocompaction in shallow silty salt marsh clay. Sedimentary Geology 223: 310-319.

Basma, A.A., A.S. Al-Homoud, A.I. Husein Malkawi, and M.A. AlBashabsheh. 1996. Swelling-shrinkage behavior of natural expansive clays. Applied Clay Science 11: 211-227.

Blankespoor, B., S. Dasgupta, and B. Laplante. 2014. Sea-level rise and coastal wetlands. Ambio 43: 996-1005.

Bockelmann, A.C., J.P. Bakker, R. Neuhaus, and J. Lage. 2002. The relation between vegetation zonation, elevation and inundation frequency in a Wadden Sea salt marsh. Aquatic Botany 73: 211-221.

Brown, C., E. Corcoran, P. Herkenrath, and J. Thonell. 2006. Marine and coastal ecosystems and human well-being: synthesis. Nairobi: United Nations Environment Programme.

Cahoon, D.R., D.J. Reed, and J.W. Day Jr. 1995. Estimating shallow subsidence in microtidal salt marshes of the southeastern United States: Kaye and Barghoorn revisited. Marine Geology 128: 1-9.

Christiansen, T., P.L. Wiberg, and T.G. Milligan. 2000. Flow and sediment transport on a tidal salt marsh surface. Estuarine, Coastal and Shelf Science 50: 315-331.

Church, J.A., P.U. Clark, A. Cazenave, J.M. Gregory, S. Jevrejeva, A. Levermann, M.A. Merrifield, G.A. Milne, R.S. Nerem, P.D. Nunn, A.J. Payne, W.T. Pfeffer, D. Stammer, and A.S. Unnikrishnan. 2013. Sea Level Change. In Climate change 2013: The physical science basis, ed. T.F. Stocker, D. Qin, G.-K. Plattner, M. Tignor, S.K. Allen, J. Boschung, A. Nauels, Y. Xia, V. Bex, and P.M. Midgley. Cambridge, New York: Cambridge University Press.

Clemmensen, L.B., K.W.T. Hansen, and A. Kroon. 2014. Storminess variation at Skagen, northern Denmark since AD 1860: Relations to climate change and implications for coastal dunes. Aeolian Research 15: 101-112.

Cooper, N.J., T. Cooper, and F. Burd. 2001. 25 years of salt marsh erosion in Essex: Implications for coastal defence and nature conservation. Journal of Coastal Conservation 7: 31-40.

Crosby, S.C., D.F. Sax, M.E. Palmer, H.S. Booth, L.A. Deegan, M.D. Bertness, and H.M. Leslie. 2016. Salt marsh persistence is threatened by predicted sea-level rise. Estuarine, Coastal and Shelf Science 181: 93-99.

D’Alpaos, A., S.M. Mudd, and L. Carniello. 2011. Dynamic response of marshes to perturbations in suspended sediment concentrations and rates of relative sea level rise. Journal of Geophysical Research 116(F04020). https://doi.org/10.1029/2011JF002093.

De Groot, A.V., A.P. Oost, R.M. Veeneklaas, E.J. Lammerts, W.E. Van Duin, and B.K. van Wesenbeeck. 2017. Tales of island tails: Biogeomorphic development and management of barrier islands. Journal of Coastal Conservation 21: 409-419.

De Groot, A.V., R.M. Veeneklaas, and J.P. Bakker. 2011. Sand in the salt marsh: Contribution of high-energy conditions to salt-marsh accretion. Marine Geology 282: 240-254.

Dijkema, K.S., H.F. Van Dobben, E.C. Koppenaal, E.M. Dijkman, and W.E. van Duin. 2011. Kweldervegetatie Ameland 1986-2010: effecten van bodemdaling en opslibbing op Neerlands Reid en De Hon. In Monitoring effecten van bodemdaling op Ameland-Oost, ed. Begeleidingscommissie Monitoring Bodemdaling Ameland. https://waddenzee.nl/fileadmin/content/Bodemdaling/2011/pdf/ Rapport_Deel_2_kwelders.pdf.

Dijkema, K.S., and W.J. Wolff. 1983. Flora and vegetation of the Wadden Sea islands and coastal areas: final report of the section 'Flora and vegetation of the islands' of the Wadden Sea Working Group. Report Wadden Sea Working Group (no. 9). Leiden: Stichting Veth tot Steun aan Waddenonderzoek.

Ehlers, J. 1988. The morphodynamics of the Wadden Sea. Rotterdam: Balkema.

Elschot, K., T.J. Bouma, S. Temmerman, and J.P. Bakker. 2013. Effects of long-term grazing on sediment deposition and salt-marsh accretion rates. Estuarine, Coastal and Shelf Science 133: 109-115.

Elschot, K., J.P. Bakker, S. Temmerman, J. Van de Koppel, and T.J. Bouma. 2015. Ecosystem engineering by large grazers enhances carbon stocks in a tidal salt marsh. Marine Ecology Progress Series 537: 9-21.

Elschot, K., A. De Groot, K. Dijkema, C. Sonneveld, J.T. Van der Wal, P. De Vries, B. Brinkman, W. Van Duin, W. Molenaar, J. Krol, L. Kuiters, D. De Vries, R. Wegman, P. Slim, E. Koppenaal, and J. de Vlas. 2017. Ontwikkeling kwelder Ameland-Oost; Evaluatie bodemdalingsonderzoek 1986-2016. In Monitoring effecten van bodemdaling op Oost-Ameland, ed. J. de Vlas, 185-328. http:// edepot.wur.nl/425069

Erchinger, H.F., H.G. Coldewey, and C. Meyer. 1996. Interdisziplinäre Erforschung des Deichvorlandes im Forschungsvorhaben "Erosionsfestigkeit von Hellern.” Die Küste 58: 1-45.

Esselink, P., W.E. Van Duin, J. Bunje, J. Cremer, E.O. Folmer, J. Frikke, M. Glahn, A.V. De Groot, N. Hecker, U. Hellwig, K. Jensen, P. Körber, J. Petersen, and M. Stock. 2017. Salt marshes. In Wadden Sea Quality Status Report 2017, update 01.03.20, ed. S. Kloepper et al. https://qsr.waddensea-worldheritage.org/reports/salt-marshes

Fagherazzi, S., M.L. Kirwan, S.M. Mudd, G.R. Guntenspergen, S. Temmerman, A. D'Alpaos, J. Van de Koppel, J.M. Rybczyk, E. Reyes, C. Craft, and J. Clough. 2012. Numerical models of salt marsh evolution: ecological, geomorphic, and climatic factors. Reviews of Geophysics v. 50, RG1002. https://doi.org/10.1029/ 2011RG000359

Fagherazzi, S., G. Mariotti, N. Leonardi, A. Canestrelli, W. Nardin, and W.S. Kearney. 2020. Salt marsh dynamics in a period of accelerated sea level rise. JGR Earth Surface 125(8). https://doi.org/10. 1029/2019JF005200

French, J.R. 2006. Tidal marsh sedimentation and resilience to environmental change: Exploratory modelling of tidal, sea-level and sediment supply forcing in predominantly allochthonous systems. Marine Geology 235: 119-136.

French, J.R., and T. Spencer. 1993. Dynamics of sedimentation in a tide-dominated backbarrier salt marsh, Norfolk, UK. Marine Geology 110: 315-331. 
French, J.R., T. Spencer, A.L. Murray, and N. Arnold. 1995. Geostatistical analysis of sediment deposition in two small tidal wetlands, Norfolk, U.K. Journal of Coastal Research 11: 308-321.

Friedrichs, C.T., and J.E. Perry. 2001. Tidal salt marsh morphodynamics: A synthesis. Journal of Coastal Research SI 27: 7-37.

Gedan, K.B., M.L. Kirwan, E. Wolanski, E.B. Barbier, and B.R. Silliman. 2011. The present and future role of coastal wetland vegetation in protecting shorelines: Answering recent challenges to the paradigm. Climatic Change 106: 7-29.

Goodwin, G.C.H., and S.M. Mudd. 2019. High platform elevations highlight the role of storms and spring tides in salt marsh evolution. Frontiers in Environmental Science 7 (62). https://doi.org/ 10.3389/fenvs.2019.00062

He, C., J. Bartholdy, and C. Christiansen. 2012. Clay mineralogy, grain size distribution and their correlations with trace metals in the salt marsh sediments of the Skallingen barrier spit, Danish Wadden Sea. Environmental Earth Sciences 67: 759-769.

Horton, B.P., I. Shennan, S.L. Bradley, N. Cahill, M. Kirwan, R.E. Kopp, and T.A. Shaw. 2018. Predicting marsh vulnerability to sealevel rise using Holocene relative sea-level data. Nature Communications 9: 2687. https://doi.org/10.1038/s41467-018-05080-0.

IPCC. 2021. Climate Change 2021: The physical science basis. Contribution of Working Group I to the sixth assessment report of the intergovernmental panel on climate change, ed. V. MassonDelmotte, P. Zhai, A. Pirani, S.L. Connors, C. Péan, S. Berger, N. Caud, Y. Chen, L. Goldfarb, M.I. Gomis, M. Huang, K. Leitzell, E. Lonnoy, J.B.R. Matthews, T.K. Maycock, T. Waterfield, O. Yelekçi, R. Yu, and B. Zhou. Cambridge University Press: in press.

Jankowski, K.L., T.E. Törnqvist, and A.M. Fernandes. 2017. Vulnerability of Louisiana's coastal wetlands to present-day rates of relative sea-level rise. Nature Communications 8: 14792. https://doi. org/10.1038/ncomms14792.

Kirwan, M.L., G.R. Guntenspergen, A. D’Alpaos, J.T. Morris, S.M. Mudd, and S. Temmerman. 2010. Limits on the adaptability of coastal marshes to rising sea level. Geophysical Research Letters 37: L23401. https://doi.org/10.1029/2010GL045489.

Kirwan, M.L., and J.P. Megonigal. 2013. Tidal wetland stability in the face of human impacts and sea-level rise. Nature 504: 53-60.

Kirwan, M.L., S. Temmerman, E.E. Skeehan, G.R. Guntenspergen, and S. Fagherazzi. 2016. Overestimation of marsh vulnerability to sea level rise. Nature Climate Change 6: 253-260.

Klein Tank, A., J. Beersma, J. Bessembinder, B. Van den Hurk, and G. Lenderink. 2015. KNMI'14: climate scenarios for the Netherlands. De Bilt: KNMI. http://www.klimaatscenarios.nl/brochures/ images/Brochure_KNMI14_EN_2015.pdf

Leendertse, P.C., A.J.M. Roozen, and J. Rozema. 1997. Long-term changes (1953-1990) in the salt marsh vegetation at the Boschplaat on Terschelling in relation to sedimentation and flooding. Plant Ecology 132: 49-58.

Leonard, L.A., A.C. Hine, and M.E. Luther. 1995. Surficial sediment transport and deposition processes in a Juncus roemerianus marsh, West-Central Florida. Journal of Coastal Research 11: 322-336.

Leonard, L.A., P.A. Wren, and R.L. Beavers. 2002. Flow dynamics and sedimentation in Spartina alterniflora and Phragmites australis marshes of the Chesapeake Bay. Wetlands 22: $415-424$

Leonardi, N., I. Carnacina, C. Donatelli, N.K. Ganju, A.J. Plater, M. Schuerch, and S. Temmerman. 2018. Dynamic interactions between coastal storms and salt marshes: A review. Geomorphology 301: 92-107.

Lovelock, C.E., D.R. Cahoon, D.A. Friess, G.R. Guntenspergen, K.W. Krauss, R. Reef, K. Rogers, M.L. Saunders, F. Sidik, A. Swales, N. Saintilan, L.X. Thuyen, and T. Triet. 2015. The vulnerability of Indo-Pacific mangrove forests to sea-level rise. Nature 526: 559-563.
Lynch, J.C., P. Hensel, and D. R. Cahoon. 2015. The surface elevation table and marker horizon technique: A protocol for monitoring wetland elevation dynamics. Natural Resource Report NPS/NCBN/NRR—2015/1078. National Park Service, Fort Collins, Colorado.

Marin-Diaz, B., L.L. Govers, D. Van Der Wal, H. Olff, and T.J. Bouma. 2021. How grazing management can maximize erosion resistance of salt marshes. Journal of Applied Ecology 00: 1-12. https://doi.org/10.1111/1365-2664.13888.

Mcleod, E., G.L. Chmura, S. Bouillon, R. Salm, M. Bjork, C.M. Duarte, C.E. Lovelock, W.H. Schlesinger, and B.R. Silliman. 2011. A blueprint for blue carbon: Toward an improved understanding of the role of vegetated coastal habitats in sequestering CO2. Frontiers in Ecology and the Environment 9: 552-560.

Montgomery, D.C., and E.A. Peck. 1982. Introduction to linear regression analysis. New York: Wiley.

Morris, J.T., P.V. Sundareshwar, C.T. Nietch, B. Kjerfve, and D.R. Cahoon. 2002. Responses of coastal wetlands to rising sea level. Ecology 83: 2869-2877.

Mudd, S.M., A. D’Alpaos, and J.T. Morris. 2010. How does vegetation affect sedimentation on tidal marshes? Investigating particle capture and hydrodynamic controls on biologically mediated sedimentation. Journal of Geophysical Research 115: F03029. https://doi.org/10.1029/2009JF001566.

Nicholls, R.J., D. Lincke, J. Hinkel, S. Brown, A.T. Vafeidis, B. Meyssignac, S.E. Hanson, J.-L. Merkens, and J. Fang. 2021. A global analysis of subsidence, relative sea-level change and coastal flood exposure. Nature Climate Change 11: 338-342.

Nolte, S., P. Esselink, J.P. Bakker, and C. Smit. 2015. Effects of livestock species and stocking density on accretion rates in grazed salt marshes. Estuarine, Coastal and Shelf Science 152: 109-115.

Nolte, S., E.C. Koppenaal, P. Esselink, K.S. Dijkema, M. Schuerch, A.V. De Groot, J.P. Bakker, and S. Temmerman. 2013a. Measuring sedimentation in tidal marshes: A review on methods and their applicability in biogeomorphological studies. Journal of Coastal Conservation 17: 301-325.

Nolte, S., F. Müller, M. Schuerch, A. Wanner, P. Esselink, J.P. Bakker, and K. Jensen. 2013b. Does livestock grazing affect sediment deposition and accretion rates in salt marshes? Estuarine, Coastal and Shelf Science 135: 296-305.

Olff, H., J. De Leeuw, J.P. Bakker, R.J. Platerink, H.J. Van Wijnen, and W. de Munck. 1997. Vegetation succession and herbivory on a salt marsh: Changes induced by sea level rise and silt deposition along an elevational gradient. Journal of Ecology 85: 799-814.

Oost, A.P., P. Hoekstra, A. Wiersma, B. Flemming, E.J. Lammerts, M. Pejrup, J. Hofstede, B. Van der Valk, P. Kiden, J. Bartholdy, M.W. Van der Berg, P.C. Vos, S. De Vries, and Z.B. Wang. 2012. Barrier island management: Lessons from the past and directions for the future. Ocean and Coastal Management 68: 18-38.

Parkinson, R.W., C. Craft, R.D. DeLaune, J.F. Donoghue, M. Kearney, J.F. Meeder, J. Morris, and R.E. Turner. 2017. Marsh vulnerability to sea-level rise. Nature Climate Change 7: 756.

Piening, H., W. Van der Veen, and R. van Eijs. 2017. Bodemdaling. In Monitoring Effecten van Bodemdaling op Oost-Ameland, ed. J. de Vlas, 9-25. www.waddenzee.nl/fileadmin/content/Bodemdaling/ 2017/Hoofdstuk_1_Bodemdaling.pdf.

Rahmstorf, S. 2007. A semi-empirical approach to projecting future sea-level rise. Science 315: 368-370.

Ratliff, K.M., A.E. Braswell, and M. Marania. 2015. Spatial response of coastal marshes to increased atmospheric $\mathrm{CO}_{2}$. PNAS 112: $15580-15584$.

Reef, R., T. Spencer, I. Möller, C.E. Lovelock, E.K. Christie, A.L. McIvor, B.R. Evans, and J.A. Tempest. 2017. The effects of elevated $\mathrm{CO}_{2}$ and eutrophication on surface elevation gain in a European salt marsh. Global Change Biology 23: 881-890. 
Rodríguez, J.F., P.M. Saco, S. Sandi, N. Saintilan, and G. Riccardi. 2017. Potential increase in coastal wetland vulnerability to sealevel rise suggested by considering hydrodynamic attenuation effects. Nature Communications 8: 16094. https://doi.org/10. 1038/ncomms 16094.

Roner, M., A. D’Alpaos, M. Ghinassi, M. Marani, S. Silvestri, E. Franceschinis, and N. Realdon. 2016. Spatial variation of saltmarsh organic and inorganic deposition and organic carbon accumulation: Inferences from the Venice lagoon, Italy. Advances in Water Resources 93: 276-287.

Roozen, A.J.M., and V. Westhoff. 1985. A study on long-term saltmarsh succession using permanent plots. Vegetatio 61: 23-32.

Sassi, M., M. Duran-Matute, T. Van Kessel, and T. Gerkema. 2015. Variability of residual fluxes of suspended sediment in a multiple tidal-inlet system: The Dutch Wadden Sea. Ocean Dynamics 65: 1321-1333.

Schepers, L., M. Kirwan, G. Guntenspergen, and S. Temmerman. 2017. Spatio-temporal development of vegetation die-off in a submerging coastal marsh. Limnology and Oceanography 62: 137-150.

Schrama, M., M.P. Berg, and H. Olff. 2012. Ecosystem assembly rules: The interplay of green and brown webs during salt marsh succession. Ecology 93: 2353-2364.

Schuerch, M., J. Rapaglia, V. Liebetrau, A. Vafeidis, and K. Reise. 2012. Salt marsh accretion and storm tide variation: An example from a barrier island in the North Sea. Estuaries and Coasts 35: 486-500.

Schuerch, M., T. Spencer, S. Temmerman, M.L. Kirwan, C. Wolff, D. Lincke, C.J. McOwen, M.D. Pickering, R. Reef, A.T. Vafeidis, J. Hinkel, R.J. Nicholls, and S. Brown. 2018. Future response of global coastal wetlands to sea-level rise. Nature 561: 231-234.

Schuerch, M., A. Vafeidis, T. Slawig, and S. Temmerman. 2013. Modeling the influence of changing storm patterns on the ability of a salt marsh to keep pace with sea level rise. Journal of Geophysical Research: Earth Surface 118: 1-13.

Schuerch, M., T. Dolch, K. Reise, and A.T. Vafeidis. 2014. Unravelling interactions between salt marsh evolution and sedimentary processes in the Wadden Sea (southeastern North Sea). Progress in Physical Geography 38: 691-715.

Shepard, C.C., C.M. Crain, and M.W. Beck. 2011. The protective role of coastal marshes: A systematic review and meta-analysis. PLoS ONE 6: e27374. https://doi.org/10.1371/journal.pone.0027374.

Slim, P.A., R.M.A. Wegman, M.E. Sanders, H.P.J. Huiskes, and H.F. Van Dobben. 2011. Monitoring kwelderrand Oerderduinen; Onderzoek naar de effecten van bodemdaling door gaswinning op de morfologie en vegetatie van de kuststrook ten zuiden van Het Oerd en de Oerderduinen op Oost-Ameland. In Monitoring effecten van bodemdaling op Ameland-Oost, ed. 125-176. Begeleidingscommissie Monitoring Bodemdaling Ameland. http://www. waddenzee.nl/fileadmin/content/Bodemdaling/2011/pdf/Rapport Deel_1_morfologie.pdf.

Spencer, T., M. Schuerch, R.J. Nicholls, J. Hinkel, D. Lincke, A.T. Vafeidis, R. Reef, L. McFadden, and S. Brown. 2016. Global coastal wetland change under sea-level rise and related stresses: The DIVA wetland change model. Global and Planetary Change 139: $15-30$.

Stark, J., T. Van Oyen, P. Meire, and S. Temmerman. 2015. Observations of tidal and storm surge attenuation in a large tidal marsh. Limnology and Oceanography 60: 1371-1381.

Stumpf, R.P. 1983. The process of sedimentation on the surface of a salt marsh. Estuarine, Coastal and Shelf Science 17: 495-508.

Symonds, M.R.E., and A. Moussalli. 2011. A brief guide to model selection, multimodel inference and model averaging in behavioural ecology using Akaike's information criterion. Behavioral Ecology and Sociobiology 65: 13-21.
Temmerman, S., T.J. Bouma, G. Govers, and D. Lauwaet. 2005. Flow paths of water and sediment in a tidal marsh: Relations with marsh developmental stage and tidal inundation height. Estuaries 28: 338-352.

Temmerman, S., G. Govers, P. Meire, and S. Wartel. 2003a. Modelling long-term tidal marsh growth under changing tidal conditions and suspended sediment concentrations, Scheldt estuary, Belgium. Marine Geology 193: 151-169.

Temmerman, S., G. Govers, P. Meire, and S. Wartel. 2004. Simulating the long-term development of levee-basin topography on tidal marshes. Geomorphology 63: 39-55.

Temmerman, S., G. Govers, S. Wartel, and P. Meire. 2003b. Spatial and temporal factors controlling short-term sedimentation in a salt and freshwater tidal marsh, Scheldt estuary, Belgium, SW Netherlands. Earth Surface Processes and Landforms 28: 739-755.

Temmerman, S., P. Meire, T.J. Bouma, P.M.J. Herman, T. Ysebaert, and H.J. de Vriend. 2013. Ecosystem-based coastal defence in the face of global change. Nature 504: 79-83.

Thiéblemont, R., G. Le Cozannet, A. Toimil, B. Meyssignac, and I. Losada. 2019. Likely and high-end impacts of regional sea-level rise on the shoreline change of European sandy coasts under a high greenhouse gas emissions scenario. Water 2019 (11): 2607. https://doi.org/10.3390/w11122607.

Townend, I., C. Fletcher, M. Knappen, and K. Rossington. 2011. A review of salt marsh dynamics. Water and Environment Journal 25: 477-488.

Van den Hurk, B., P. Siegmund, and A. Klein Tank (eds.). 2014. KNMI'14: climate change scenarios for the 21 st century - a Netherlands perspective. De Bilt: KNMI.

Van Dobben, H.F., and P.A. Slim. 2012. Past and future plant diversity of a coastal wetland driven by soil subsidence and climate change. Climatic Change 110: 597-618.

Van Duin, W.E., K.S. Dijkema, and J. Zegers. 1997. Veranderingen in bodemhoogte (opslibbing, erosie en inklink) in de Peazemerlannen. IBN-rapport 326. Wageningen: Instituut voor Bos- en Natuuronderzoek. https://edepot.wur.nl/369603

Van Straaten, L.M.J.U. 1954. Composition and structure of recent marine sediments in the Netherlands. Leidse Geologische Mededelingen 19: 1-108.

Van Wijnen, H.J., and J.P. Bakker. 1997. Nitrogen accumulation and plant species replacement in three salt marsh systems in the Wadden Sea. Journal of Coastal Conservation 3: 19-26.

Van Wijnen, H.J., and J.P. Bakker. 1999. Nitrogen and phosphorus limitation in a coastal barrier salt marsh: The implications for vegetation succession. Journal of Ecology 87: 265-272.

Van Wijnen, H.J., and J.P. Bakker. 2001. Long-term surface elevation change in salt marshes: A prediction of marsh response to future sea-level rise. Estuarine, Coastal and Shelf Science 52: 381-390.

Vermeersen, B.L.A., A.B.A. Slangen, Th. Gerkema, F. Baart, K.M. Cohen, S. Dangendorf, M. Duran-Matute, Th. Frederikse, A. Grinsted, M.P. Hijma, S. Jevrejeva, P. Kiden, M. Kleinherenbrink, E.W. Meijles, M.D. Palmer, R. Rietbroek, R.E.M. Riva, E. Schulz, D.C. Slobbe, M.J.R. Simpson, P. Sterlini, P. Stocchi, R.S.W. van de Wal and M. van der Wegen. 2018. Sea-level change in the Dutch Wadden Sea. Netherlands Journal of Geosciences 97: 79-127.

Wang, Z.B., E.P.L. Elias, A.J.F. Van der Spek, and Q.J. Lodder. 2018. Sediment budget and morphological development of the Dutch Wadden Sea: Impact of accelerated sea-level rise and subsidence until 2100. Netherlands Journal of Geosciences 97: 183-214.

Wiberg, P.L., S. Fagherazzi, and M.L. Kirwan. 2020. Improving predictions of salt marsh evolution through better integration of data and models. Annual Review of Marine Science 2020 (12): 389-413. 